
\title{
Reserarch Sulure \\ Distribution of plutonium in the Pacific Ocean and implications for tracing of ocean circulation
}

Junwen Wu ( $\nabla$ qdwjunwen@163.com )

Shantou University

Jisheng Chen

Shantou University

Cui Wang

Third Institute of Oceanography, Ministry of Natural Resource

\section{Zhaoyong Zheng}

South China Sea Marine Engineering and Environment Institute, State Oceanic Administration Liang Wang

South China Sea Marine Engineering and Environment Institute, State Oceanic Administration

\section{Research Article}

Keywords: Plutonium, Pacific Proving Grounds, Pacific Ocean, Kuroshio, North Equatorial Current

Posted Date: May 28th, 2021

DOl: https://doi.org/10.21203/rs.3.rs-564529/v1

License: (c) (1) This work is licensed under a Creative Commons Attribution 4.0 International License. Read Full License 

tracing of ocean circulation

\author{
Junwen $\mathrm{Wu}^{1,3^{*}}$, Jisheng Chen ${ }^{1}$, Cui Wang ${ }^{2 *}$, Zhaoyong Zheng ${ }^{4}$, Liang Wang ${ }^{4}$
}

5 1. Institute of Marine Sciences \& Guangdong Provincial Key Laboratory of Marine Biotechnology, Shantou University, Shantou 515063, China 


\section{ABSTRACT}

This study examined plutonium $(\mathrm{Pu})$ sources and distribution in the Pacific Ocean based on extensive field datasets over the past 50 years. The basin wide ${ }^{240} \mathrm{Pu} /{ }^{239} \mathrm{Pu}$ atom ratios in surface and deep seawater ranged from 0.192 to 0.279 averaging $0.235 \pm 0.019$, a value consistently higher than that of global fallout at $\sim 0.180$. The distribution of ${ }^{240} \mathrm{Pu} /{ }^{239} \mathrm{Pu}$ atom ratios exhibited a decreasing trend along the North Equatorial Current-

31 Kuroshio to their extension areas. The activity levels of ${ }^{239+240} \mathrm{Pu}$ in Pacific Ocean surface seawater ranged widely from 0.2 to $43.5 \mathrm{mBq} \mathrm{m}^{-3}$, and increased with latitude. We determined the Pu sourced from the Pacific Proving Grounds (PPG) and global nuclear fallout in the Pacific Ocean based on the Pu isotopic composition. Using a mixing model, we found that the PPG made the dominant Pu contribution (average=69.6 $\pm 14.4 \%$ ) to Pacific Ocean surface seawater. The depth range of maximal ${ }^{239+240} \mathrm{Pu}$ activity in the Pacific 


\section{Introduction}

The main sources of the man-made radionuclide plutonium $(\mathrm{Pu})$ in the Pacific are the deposition of global and close-in fallout due to atmospheric nuclear tests ${ }^{1-2}$. It has been reported that the ${ }^{239+240} \mathrm{Pu}$ inventory is $\sim 8.5$ petabecquerels $\left(1 \mathrm{PBq}=10^{15} \mathrm{~Bq}\right)$ in the Pacific Ocean $^{3}$. The environmental risk of $\mathrm{Pu}$ has become of considerable public concern due to its high radioactivity and danger even at small doses. $\mathrm{Pu}$ is also a good tracer to study ocean current trajectories ${ }^{4}$. Additionally, the specific Pu sources can be identified according to the characteristic value of the $\mathrm{Pu}$ isotopic ratio ${ }^{5}$.

Accurate Pu measurement is critical for the study of this element in the environment. In general, the conventional analytical method of $\mathrm{Pu}$ is $\alpha$-spectrometry. However, there are clear disadvantages associated with this method, such as the inability to distinguish between ${ }^{239} \mathrm{Pu}$ and ${ }^{240} \mathrm{Pu}$, requirement for labor-intensive pretreatment work, need for a large-volume sample ( $>100 \mathrm{~L})$ and long counting time ${ }^{6}$. In the past 30 years, various $\mathrm{Pu}$ analytical methods have been developed for use with environmental samples including the rapid development of mass spectrometry (MS), e.g., multiple collector inductively coupled $\mathrm{MS}^{7}$, accelerator $\mathrm{MS}^{8}$ and ICP-MS ${ }^{9}$. However, the determination of Pu using the MS is expensive due to the high cost of instrumentation. Therefore, compared to routine monitoring, such as that of temperature-salinity (T-S) and nutrient data, the available field $\mathrm{Pu}$ datasets in the ocean are very limited. This makes it difficult to improve our understanding of the chemical behavior and distribution patterns of plutonium in the ocean. Therefore, it is necessary to synthesize a large amount of existing field $\mathrm{Pu}$ datasets to ascertain the Pu behavior in the ocean.

Plutonium derived from the Pacific Proving Grounds (PPG) in the equatorial Pacific islands is well known and is characterized by high atomic ratios of ${ }^{240} \mathrm{Pu} /{ }^{239} \mathrm{Pu}(0.30$ $0.36)^{10-11}$. Previous studies suggested that the PPG released Pu could be transported to the northwestern Pacific via the North Equatorial Current (NEC) and Kuroshio ${ }^{1,10,12}$. These studies indicated that Pu from the PPG is a promising tracer of ocean currents in the Pacific Ocean. Additionally, the input of Pu from the PPG resulted in a high Pu inventory in the North Pacific Ocean ${ }^{1,10,13-14}$. However, the vertical structure of the ${ }^{239+240} \mathrm{Pu}$ inventory remains unclear. Furthermore, it was suggested that the 2011 Fukushima Nuclear Accident (FNA) exerted no immediate Pu impact on the northwestern Pacific Ocean ${ }^{12,15-19}$. Overall, 
the limited available Pu data usually cover a local area, and therefore cannot yield unbiased interpretation for the Pacific Ocean as a whole. Large Pu dataset in both surface and deep water are rarely available simultaneously for the Pacific Ocean, thus limiting our ability to fully understand the chemical behavior of $\mathrm{Pu}$ in the open ocean.

The present study examined the source functions and aimed to gain a better understanding of the fundamental processes that control the transport and fate of $\mathrm{Pu}$ by combining large field datasets obtained in the past 50 years. It provides baseline $\mathrm{Pu}$ data with sufficient resolution to define a basin-wide distribution. Meanwhile, it is worthwhile noting that the Japanese government plans to discharge the FNA sewage to the Pacific Ocean. Information on $\mathrm{Pu}$ isotopes helps in future environmental assessment and understanding of the Pu biogeochemical cycle in the Pacific Ocean, and allows proposing of future Pu studies in the ocean.

\section{Materials and methods}

\subsection{Study area}

The Pacific Ocean is the largest ocean worldwide, and is characterized by a unique ocean circulation pattern, which makes the region of particular interest for oceanographic studies. The Pacific Ocean's surface circulation includes the North Pacific surface

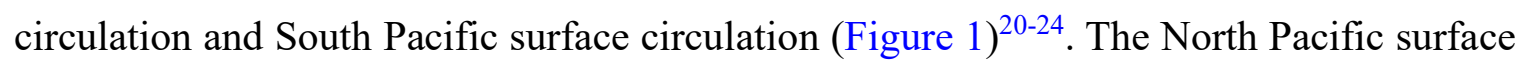
circulation is mainly consisted of the eastward subarctic current and the westward $\mathrm{NEC}^{25}$. The NEC is divided into the Kuroshio (northern branch) and the Mindanao Currents (southern branch) ${ }^{26}$. The western boundary current - Kuroshio plays an important role in heat and mass transport between the equatorial and northwestern Pacific ${ }^{27}$. The eastwardflowing Kuroshio extension splits into a southward branch and an eastward flow in the nearby of the Shatsky Rise. The former serves to create Kuroshio Countercurrent and the latter becomes the North Pacific Current ${ }^{21}$. The eastern boundary current in the North Pacific's subtropical gyre is the California Current. In contrast, the South Pacific surface circulation mainly comprises the South Pacific Current (Figure 1) ${ }^{28}$ and South Equatorial Current $^{21}$. The western and eastern boundary currents in the South Pacific are the East Australian current and the Peru current, respectively ${ }^{21}$. 


\subsection{Data sources}

We reviewed over 400 datasets of ${ }^{239+240} \mathrm{Pu}$ in Pacific Ocean encompassing the past 50 years, and including surface and deep water measurement. These Pu data were mainly extracted from published databases including ScienceDirect, the Web of Science and Scopus, Google Scholar, using the keywords "plutonium and ${ }^{240} \mathrm{Pu} /{ }^{239} \mathrm{Pu}$ atom ratio" as well as the primary keyword "Pacific Ocean seawater". Values reported throughout this study represent the mean \pm standard deviation (SD).

\section{Results and discussion}

\subsection{Horizontal distribution of Pu isotopes in the Pacific Ocean}

\subsection{1. ${ }^{240} \mathrm{Pu} /{ }^{239} \mathrm{Pu}$ atom ratios}

Over 50 datasets of ${ }^{240} \mathrm{Pu} /{ }^{239} \mathrm{Pu}$ atomic ratios in Pacific Ocean surface seawater were summarized from previously published studies ${ }^{4,12,29-33}$ and their horizontal distribution was plotted in Figure 2. The ${ }^{240} \mathrm{Pu} /{ }^{239} \mathrm{Pu}$ atom ratios over the period 1973-2015 varied from 0.195 to 0.279 , averaging $0.242 \pm 0.021(\mathrm{n}=37)$. Spatially, the ${ }^{240} \mathrm{Pu} /{ }^{239} \mathrm{Pu}$ atomic ratios in the Kuroshio mainstream zone and its extension of the northwestern Pacific Ocean varied from 0.243 to 0.263 (average $=0.253 \pm 0.007, \mathrm{n}=7$ ) and from 0.228 to 0.232 (average $=0.230$ $\pm 0.003, \mathrm{n}=2)$, respectively ${ }^{12}$. The distribution of the ${ }^{240} \mathrm{Pu} /{ }^{239} \mathrm{Pu}$ atomic ratio exhibited a gradual decrease in the direction of the subarctic gyre, declining along the Kuroshio from the eastern Philippines to southern Japan (Figure 2a). In contrast, the ${ }^{240} \mathrm{Pu} /{ }^{239} \mathrm{Pu}$ atomic ratios off the Kuroshio zone varied from 0.199 to 0.244 , averaging $0.222 \pm 0.019(\mathrm{n}=8)$, values which were lower than those in the mainstream zone of Kuroshio ${ }^{12}$. It is noteworthy that higher ${ }^{240} \mathrm{Pu} /{ }^{239} \mathrm{Pu}$ atom ratios were observed in the converging zone between the Kuroshio and the Oyashio, ranging from 0.233 to 0.279 (average $=0.257 \pm 0.015, \mathrm{n}=11)^{29,32}$. In the subarctic zone, ${ }^{240} \mathrm{Pu} /{ }^{239} \mathrm{Pu}$ atomic ratios were in the range of $0.237-0.254$, averaging $0.247 \pm 0.007(n=6)^{29}$, i.e., were lower than those in the mainstream zone of Kuroshio. In the South Pacific Ocean, ${ }^{240} \mathrm{Pu} /{ }^{239} \mathrm{Pu}$ atomic ratios varied from 0.195 to 0.215 (average $=0.205 \pm 0.014, \mathrm{n}=2)^{31}$, and were thus slightly lower than those in the North Pacific.

Overall, the ${ }^{240} \mathrm{Pu} /{ }^{239} \mathrm{Pu}$ atomic ratios in Pacific Ocean surface seawater are 
substantially higher (by 34.4\%) than the values from global fallout, indicating that this area has received non-global $\mathrm{Pu}$ fallout. Potential non-global fallout sources of $\mathrm{Pu}$ include lowlatitude above-ground nuclear weapons test sites located within the basin (i.e., the PPG), Fukushima derived from nuclear contamination, the Chernobyl nuclear accident and Asian dust derived from aboveground nuclear tests conducted by the People's Republic of China (PRC) at the Lop Nor and/or the Semipalatinsk sites. During the period 1952-1958, extensive US nuclear bomb tests were carried on the Pacific Marshall Islands, which yielded fallout accounting for $>50 \%$ of total fallout at the time ${ }^{10}$. It is well known that these events resulted in higher ${ }^{240} \mathrm{Pu} /{ }^{239} \mathrm{Pu}$ atomic ratios $(0.30-0.36)^{11}$. The contribution of Chernobyl-derived $\mathrm{Pu}$ was confirmed to be negligible in the North Pacific Ocean ${ }^{34}$. The atomic ratios of ${ }^{241} \mathrm{Pu} /{ }^{239} \mathrm{Pu}$ and ${ }^{240} \mathrm{Pu} /{ }^{239} \mathrm{Pu}$ in seawater and marine sediments suggested that the Pu signal from the immediate impact and atmospheric deposition from the FNA was minor in the Pacific Ocean ${ }^{12,16,18,35-37}$. The ${ }^{240} \mathrm{Pu} /{ }^{239} \mathrm{Pu}$ atomic ratio of $\sim 0.180$ in Chinese soil profiles is similar to the global fallout, suggesting that the Lop Nor and Semipalatinsk nuclear tests did not appear to contribute $\mathrm{Pu}$ to Chinese soil and the China Seas ${ }^{4,12,38-40}$. Considering the large distance of the Pacific Ocean from the Lop Nor and Semipalatinsk nuclear test sites relative to the China Seas, the Pu contribution from these sites appears to be negligible. Plutonium from the PPG was confirmed to be the only nonglobal source in the Pacific Ocean. Therefore, we constrained the Pu sources in the Pacific Ocean to include the PPG and global fallout, the former being continuously supplied to the Pacific Ocean via ocean circulation after the banning of nuclear tests (e.g., NEC and Kuroshio, North Pacific Current) and resulting in the differential distribution of Pu activity between North Pacific and South Pacific ${ }^{1}$.

\subsection{2 ${ }^{239+240} \mathrm{Pu}$ activity}

The ${ }^{239+240} \mathrm{Pu}$ activities in Pacific Ocean surface seawater over the period 1973-2015 derived from previous studies are summarized in Figure 2. They show a wide range from 0.2 to $43.5 \mathrm{mBq} \mathrm{m}^{-3}$, averaging $5.4 \pm 7.5 \mathrm{mBq} \mathrm{m}^{-3}(\mathrm{n}=58)^{4,12-14,29-33,41-42}$. In the North Pacific Ocean, the ${ }^{239+240} \mathrm{Pu}$ activity of surface seawater varied from 0.6 to $43.5 \mathrm{mBq} \mathrm{m}^{-3}$, averaging $5.9 \pm 7.7 \mathrm{mBq} \mathrm{m}^{-3}(\mathrm{n}=50)$. In the South Pacific Ocean, they varied from 0.2 to $17.0 \mathrm{mBq}$ $\mathrm{m}^{-3}$, with a mean value of $2.7 \pm 5.8 \mathrm{mBq} \mathrm{m}^{-3}(\mathrm{n}=8)$. In the present study, we highlight the analysis and discussion of ${ }^{239+240} \mathrm{Pu}$ activity in the North Pacific in light of the additional 
field data included.

In the northwest Pacific, ${ }^{239+240} \mathrm{Pu}$ activities in Kuroshio water were in the range of $1.15-1.93 \mathrm{mBq} \mathrm{m}^{-3}$, averaging $1.60 \pm 0.25 \mathrm{mBq} \mathrm{m}^{-3}{ }^{12}$. Outside the Kuroshio zone, they ranged from 1.18 to 2.16 (average $=1.62 \pm 0.30 \mathrm{mBq} \mathrm{m}^{-3}$ ), and were comparable to those of the Kuroshio mainstream ${ }^{12}$. In the Oyashio and the Kuroshio converging zone, ${ }^{239+240} \mathrm{Pu}$ activities ranged from 1.46 to $43.50 \mathrm{mBq} \mathrm{m}^{-3}$ (average $\left.=8.52 \pm 12.11 \mathrm{mBq} \mathrm{m}^{-3}, \mathrm{n}=11\right)^{29,32}$, and were thus higher than those of the Kuroshio mainstream. In turn, in the subarctic zone, ${ }^{239+240} \mathrm{Pu}$ activities varied from 2.30 to $20.20 \mathrm{mBq} \mathrm{m}^{-3}$, averaging $11.97 \pm 7.40 \mathrm{mBq} \mathrm{m}^{-3}$ $(\mathrm{n}=6)^{29}$. To determine whether ${ }^{239+240} \mathrm{Pu}$ activities differed within and outside the Kuroshio, an f-test and t-test were conducted using these combined data ${ }^{43}$. Results showed that ${ }^{239+240} \mathrm{Pu}$ activity in the Kuroshio water was significantly lower than those outside the Kuroshio zone (Student t-test, $\mathrm{p}<0.05$ ). This suggests that the former is readily scavenged leading to a decline in the supply of $\mathrm{Pu}$.

The bulk of $\mathrm{Pu}$ in Kuroshio water should originate mainly from the PPG. The physicochemical characteristics of particles that packaged $\mathrm{Pu}$ are closely related to those occurring under nuclear testing conditions ${ }^{10}$. In general, close-in fallout from the PPG was enclosed by calcium compounds such as calcium oxides and calcium hydroxides ${ }^{44}$. The size of PPG particles that package Pu is typically over 1 micron ${ }^{45}$. It is well known that $\mathrm{Pu}$ from the PPG adhering to relatively larger particles is more efficiently scavenged during downward transport and deposition. In contrast, the size of global fallout particles that package $\mathrm{Pu}$ is typically $0.1-1$ micron $^{44}$. Plutonium from global fallout adhering to relatively smaller particles is less efficiently scavenged in the open ocean. The retention time of $\mathrm{Pu}$ from the PPG in water is thus shorter than that of global fallout ${ }^{4,12}$. Additionally, it is reported that elevated diazotrophic concentration in Kuroshio water usually stimulates the growth of diatoms and increases the export flux of particles ${ }^{46-47}$. Actually, the Trichodesmium (nitrogen fixer) is abundant in Kuroshio water, and is positively correlated with the concentration of large diatom cells $(>10 \mu \mathrm{m})(\mathrm{p}<0.05)^{48}$. The vertical distribution of diatom abundance in Kuroshio water is consistent with that of Trichodesmium, in that the maximum abundance of both appeared at the surface ${ }^{48-49}$. In contrast, Trichodesmium in the zone outside the Kuroshio exhibited a low concentration and its vertical distribution showed no surface maxima ${ }^{50}$. This indicated that the zone outside the Kuroshio potentially 
has a lower scavenging efficiency than Kuroshio seawater, although particle abundances does not differ significantly in these two areas ${ }^{51}$. The lower ${ }^{239+240} \mathrm{Pu}$ activities in Kuroshio seawater should thus be attributable to its higher scavenging efficiency due to the abundance of Trichodesmium.

At present, the bulk of ${ }^{239+240} \mathrm{Pu}$ in Kuroshio water should originate mainly from the seawater and sediment discharge from PPG contaminated lagoons. ${ }^{239+240} \mathrm{Pu}$ activities in seawater and sediments of PPG lagoons were determined to be $\sim 455 \mathrm{mBq} \mathrm{m}^{-3}$ and $\sim 99 \mathrm{~Bq}$ $\mathrm{kg}^{-1}$, respectively ${ }^{52}$. They are 2-3 orders of magnitude higher than the background value in the earth's environment. It is estimated that the export flux of ${ }^{239+240} \mathrm{Pu}$ from the PPG is ca. 0.5 Terabecquerel/year in the North Pacific $\left(1 \mathrm{TBq}=10^{12} \mathrm{~Bq}\right)^{4,12}$. Nevertheless, this annual export flux is several orders of magnitude smaller than the delivery rate via the deposition of PPG close-in fallout over the period 1952-1958 ${ }^{12,52}$. Thus, the lower ${ }^{239+240} \mathrm{Pu}$ activities in Kuroshio water should be closely related to the decline in the PPG supply with time.

Overall, the lower ${ }^{239+240} \mathrm{Pu}$ activity in Kuroshio water is linked primarily to the higher scavenging efficiency of Kuroshio water, coinciding with a decline in the PPG supply over time. The fact that the radioactivity levels of ${ }^{239+240} \mathrm{Pu}$ in Kuroshio seawater were substantially lower than those outside the Kuroshio zone argues for high $\mathrm{Pu}$ accumulation outside the Kuroshio zone and is consistent with the rapid scavenging of $\mathrm{Pu}-$ PPG in Kuroshio water.

The horizontal distribution of ${ }^{239+240} \mathrm{Pu}$ activities shown in Figure $2 \mathrm{~b}$ is characterized by three key features: 1 ) the ${ }^{239+240} \mathrm{Pu}$ activity in the North Pacific Ocean (average $\sim 5.9$ $\mathrm{mBq} \mathrm{m}{ }^{-3}$ ) was higher than in the South Pacific Ocean (average $=\sim 2.7 \mathrm{mBq} \mathrm{m}^{-3}$ ); 2) the ${ }^{239+240} \mathrm{Pu}$ activity in the North Pacific Ocean at first increased with latitude and subsequently decreased with latitude (i.e., the maximum ${ }^{239+240} \mathrm{Pu}$ activity appeared at midlatitudes); 3) the ${ }^{239+240} \mathrm{Pu}$ activity in the South Pacific Ocean gradually decreased with increasing the latitude. This distribution pattern of ${ }^{239+240} \mathrm{Pu}$ activity is influenced by the source, transport and scavenging of $\mathrm{Pu}$. Large-scale atmospheric testing of nuclear weapons was carried out at mid-high latitudes of the northern hemisphere between the 1950s to early $1960 \mathrm{~s}^{53-54}$, such that fallout debris was largely injected into the stratosphere where it remained for about a year and was then deposited globally (so called global fallout) ${ }^{54}$. Therefore, $\mathrm{Pu}$ in the Pacific Ocean mainly originates from the deposition of global 
fallout $^{1,10,53}$ and is estimated to result in a delivery of 2.59 PBq to the North Pacific Ocean ${ }^{1}$.

240 The latitudinal distribution of $\mathrm{Pu}$ is consistent with the deposition pattern of global fallout ${ }^{1}$.

241 In the 1950s, close-in fallout from the PPG was deposited in the Pacific Ocean, and Bowen

242 et al. (1980) ${ }^{1}$ estimated that ca. 6.44 PBq of ${ }^{239+240} \mathrm{Pu}-\mathrm{PPG}$ was delivered to the North

243 Pacific Ocean. Following the moratorium of weapons tests, the NEC could bring PPG 244 contaminants westward, entering the Kuroshio and southward, entering the Equatorial 245 Countercurrent (see later discussion).

\subsection{Vertical distribution of $\mathrm{Pu}$ isotopes in the Pacific Ocean}

The vertical profile of $\mathrm{Pu}$ isotopes in the water column at 25 sites in the Pacific Ocean was summarized $1,12,14,29,31,33,41,55$ and plotted in Figure 3.

\subsection{1. ${ }^{240} \mathrm{Pu} /{ }^{239} \mathrm{Pu}$ atom ratios}

Vertical depth profile of ${ }^{240} \mathrm{Pu} /{ }^{239} \mathrm{Pu}$ atom ratios in the Pacific Ocean are shown in Figure $3 \mathrm{a}$. Those in the water column varied from 0.192 to 0.255 , averaging $0.229 \pm 0.015$ $(\mathrm{n}=46)$. Spatially, the ${ }^{240} \mathrm{Pu} /{ }^{239} \mathrm{Pu}$ atomic ratios in the North Pacific Ocean varied from 0.215 to 0.255 , averaging $0.231 \pm 0.011(\mathrm{n}=37)$, and the corresponding values in the South Pacific Ocean ranged from 0.192 to 0.251 , averaging $0.220 \pm 0.024(n=9)$. They were consistently higher than those of global fallout, suggesting that the $\mathrm{Pu}$ signature from nonglobal fallout occurs throughout the water column $(0-6000 \mathrm{~m})$. High ${ }^{240} \mathrm{Pu} /{ }^{239} \mathrm{Pu}$ atom ratios are potentially attributed to the PPG-Pu signature, via deposition in the $1950 \mathrm{~s}$ and subsequent transport in ocean circulation. The vertical patterns of ${ }^{240} \mathrm{Pu} /{ }^{239} \mathrm{Pu}$ atom ratios showed a slight increase with depth in the Pacific Ocean (Figure 3a). For example, the atom ratio at the AQ7 station of the North Pacific increased from $\sim 0.215$ at the surface to $\sim 0.230$ in the mid-water column. Similarly, the atom ratio at the AQ13 station of the South Pacific increased from $\sim 0.195$ at the surface to $\sim 0.215$ in the intermediate water. Large particles packaged Pu-PPG was preferentially scavenged during downward transport and deposition ${ }^{10}$. At mid-depth, an increase in the ${ }^{240} \mathrm{Pu} /{ }^{239} \mathrm{Pu}$ atom ratio was caused by $\mathrm{Pu}$ recycling during downward transport, where PPG-Pu goes back to the water column because of particle remineralization ${ }^{6,12}$.

Vertical patterns of ${ }^{239+240} \mathrm{Pu}$ activity in the Pacific Ocean are shown in Figure $3 b-3 \mathrm{c}$. Activities in the water column of the Pacific Ocean varied from 0.2 to $76.7 \mathrm{mBq} \mathrm{m}^{-3}$, 
averaging $13.4 \pm 14.4 \mathrm{mBq} \mathrm{m}^{-3}(\mathrm{n}=315)$. Those in the North Pacific Ocean varied from 0.6 to $76.7 \mathrm{mBq} \mathrm{m}^{-3}$, averaging $16.5 \pm 15.7 \mathrm{mBq} \mathrm{m}^{-3}(\mathrm{n}=212)$, while they ranged from 0.2 to $50.0 \mathrm{mBq} \mathrm{m}^{-3}$ in the South Pacific Ocean, with a mean value of $7.0 \pm 7.9 \mathrm{mBq} \mathrm{m}^{-3}(\mathrm{n}=103)$. Thus, overall, ${ }^{239+240} \mathrm{Pu}$ activities in the North Pacific are higher than those in the South Pacific. The vertical ${ }^{239+240} \mathrm{Pu}$ activity profile showed an initial tendency to increase with increasing water depth, featuring a sub-surface maximum, followed by a slower decrease with depth. This distribution agrees with the typical $\mathrm{Pu}$ pattern found in oceanic regimes ${ }^{1}$. The maximal ${ }^{239+240} \mathrm{Pu}$ activity in the water column of the Pacific Ocean displayed a wide range of 300-900 m, averaging $608 \pm 137 \mathrm{~m}(\mathrm{n}=25)$ (Figure 4a). In the North Pacific Ocean, the maximum ${ }^{239+240} \mathrm{Pu}$ activity ranged from 405 to $900 \mathrm{~m}$, averaging $625 \pm 117 \mathrm{~m}$ $(\mathrm{n}=17)$. In contrast, it ranged from 300 to $800 \mathrm{~m}$ in the South Pacific Ocean, averaging 572 $\pm 174 \mathrm{~m}(\mathrm{n}=8)$. The depth of maximum ${ }^{239+240} \mathrm{Pu}$ activity in the North Pacific is thus greater than that in the South Pacific. The depth of maximum $\mathrm{Pu}$ activity is also greater than the deep chlorophyll maximum $(\mathrm{DCM}<100 \mathrm{~m})$ in the Pacific ${ }^{56-57}$. As shown in Figure $4 b$, the depth of maximum ${ }^{239+240} \mathrm{Pu}$ activity in the Pacific Ocean increases with increasing latitude, i.e., the depth in the high latitude zone is greater than that at low latitudes. The relationship between the depth of maximal $\mathrm{Pu}$ activity and longitude is also plotted in Figure 4c, showing that this depth in the eastern hemisphere is more variable than in the western hemisphere. Indeed, it was determined that particle concentration was higher in the upper $100 \mathrm{~m}$ (DCM layer), which would enhance Pu scavenging in this layer. Beyond $100 \mathrm{~m}$, particle concentrations remained low, and regeneration due to decomposition of particles by microorganisms during downward transport is expected to be dominant ${ }^{4,58-59}$.

\section{3. ${ }^{239+240} \mathrm{Pu}$ inventory in the Pacific Ocean}

The ${ }^{239+240} \mathrm{Pu}$ inventory provides a useful indicator to assess its accumulation in the ocean. The Pacific Ocean water column ${ }^{239+240} \mathrm{Pu}$ inventories are summarized and plotted in Figure 5 to determine their latitudinal spatial distribution. The inventory in the Pacific Ocean showed a wide range of 7.3-148.0 $\mathrm{Bq} \mathrm{m}^{-2}$, with an average of $67.7 \pm 40.7 \mathrm{~Bq} \mathrm{~m}^{-2}$ $(\mathrm{n}=49)$. In the North Pacific it varied from 28.2 to $148.0 \mathrm{~Bq} \mathrm{~m}^{-2}$, averaging $81.2 \pm 35.8 \mathrm{~Bq}$ $\mathrm{m}^{-2}(\mathrm{n}=38)$, whereas it ranged from 7.3 to $39.7 \mathrm{~Bq} \mathrm{~m}^{-2}$ in the South Pacific, with a mean value of $20.8 \pm 9.8 \mathrm{~Bq} \mathrm{~m}^{-2}(\mathrm{n}=11)$. The ${ }^{239+240} \mathrm{Pu}$ inventory in the North Pacific is markedly 
higher than that in the South Pacific (Figure 5a), which is potentially related to the largescale nuclear bombing conducted in the northern hemisphere ${ }^{60}$. Notably, a high ${ }^{239+240} \mathrm{Pu}$ inventory was observed in the northwest Pacific (Figure 5a), presumably due to the high deposition flux of global fallout and the Pu input of PPG via the NEC and Kuroshio current. The latitudinal distribution of ${ }^{239+240} \mathrm{Pu}$ inventory is plotted in Figure 5b, showing that values were higher than the deposition flux of global fallout in the corresponding latitudinal zone. This further suggests that the Pacific Ocean has been receiving Pu from the PPG. The water column ${ }^{239+240} \mathrm{Pu}$ inventories increase with latitude in the North Pacific, whereas the inverse occurs in the South Pacific, i.e., they decrease with increasing latitude.

The ${ }^{239+240} \mathrm{Pu}$ inventory at depth $>3000 \mathrm{~m}$ (except for HY15) in the Pacific Ocean and percent of the total at three different depth ranges $(0-1000 \mathrm{~m}, 0-2000 \mathrm{~m}$ and 0-3000 $\mathrm{m})$ are listed in Table 1. The vertical distribution of the ${ }^{239+240} \mathrm{Pu}$ inventory in the Pacific Ocean showed considerable heterogeneity with water depth (Figure 6a), such that most of ${ }^{239+240} \mathrm{Pu}$ inventory occurs in the upper $1000 \mathrm{~m}$. In the South Pacific, the ${ }^{239+240} \mathrm{Pu}$ inventories at depths of 0-1000 m, 1000-2000 $\mathrm{m}$ and 2000-3000 $\mathrm{m}$ at the stations sampled ranged from 4.1-21.1 $\mathrm{Bq} \mathrm{m}^{-2}$ (average $=9.0 \pm 5.7 \mathrm{~Bq} \mathrm{~m}^{-2}$ ), 1.6-10.4 $\mathrm{Bq} \mathrm{m}^{-2}$ (average $=4.4 \pm 3.2$ $\mathrm{Bq} \mathrm{m}^{-2}$ ), 1.0-11.5 $\mathrm{Bq} \mathrm{m}^{-2}$ (average $=4.5 \pm 4.1 \mathrm{~Bq} \mathrm{~m}^{-2}$ ), respectively. Therefore, the ${ }^{239+240} \mathrm{Pu}$ inventories at $0-1000 \mathrm{~m}$ are ca. twice as high as those at $1000-2000 \mathrm{~m}$ and $2000-3000 \mathrm{~m}$. Correspondingly, the ${ }^{239+240} \mathrm{Pu}$ inventory contribution at $0-1000 \mathrm{~m}, 1000-2000 \mathrm{~m}$ and 2000$3000 \mathrm{~m}$ to the total $\mathrm{Pu}$ inventory varied from $32.7-56.0 \%$ (average $=44.0 \pm 8.3 \%$ ), $12.9-28.7 \%$ (average $=20.0 \pm 4.6 \%$ ), 7.7-33.8\% (average $=18.0 \pm 8.3 \%$ ), respectively (Figure 6b). The percent ${ }^{239+240} \mathrm{Pu}$ out of the total at $0-3000 \mathrm{~m}$ depth varied from $67.2-100.0 \%$ (average $=82.0 \pm 11.5 \%$ ). The ${ }^{239+240} \mathrm{Pu}$ inventories in the North Pacific Ocean at $0-1000 \mathrm{~m}$, 1000-2000 $\mathrm{m}$ and 2000-3000 $\mathrm{m}$ ranged from 9.6-45.2 $\mathrm{Bq} \mathrm{m}^{-2}\left(\right.$ average $\left.=25.7 \pm 10.6 \mathrm{~Bq} \mathrm{~m}^{-2}\right)$, 3.3-20.5 Bq m${ }^{-2}$ (average $=9.6 \pm 5.9 \mathrm{~Bq} \mathrm{~m}^{-2}$ ), 1.7-16.3 $\mathrm{Bq} \mathrm{m}^{-2}$ (average $=6.8 \pm 4.5 \mathrm{~Bq} \mathrm{~m}^{-2}$ ), respectively. The ${ }^{239+240} \mathrm{Pu}$ inventories at 0-1000 $\mathrm{m}$ are higher than those at $1000-3000 \mathrm{~m}$. In turn, the percent contribution of ${ }^{239+240} \mathrm{Pu}$ inventories to the total in the North Pacific Ocean at 0-1000 m, 1000-2000 $\mathrm{m}$ and 2000-3000 $\mathrm{m}$ varied from 29.7-65.5\% $($ average $=43.3 \pm 9.5 \%), 6.7-26.9 \%($ average $=15.7 \pm 5.6 \%), 2.4-33.3 \%($ average $=12.1 \pm 8.0 \%)$, respectively. This contribution in the North Pacific Ocean at 0-3000 m ranged from 53.9 to $85.0 \%$ (average $=71.1 \pm 10.7 \%$ ). Overall, the contribution of ${ }^{239+240} \mathrm{Pu}$ inventories in the 
Pacific Ocean at $0-1000 \mathrm{~m}$ and $0-3000 \mathrm{~m}$ accounted on average for $43.5 \pm 9.0 \%$ and $75.1 \pm 12.0 \%$ of the total, respectively. This vertical structure of the ${ }^{239+240} \mathrm{Pu}$ inventory is helpful to estimate the $\mathrm{Pu}$ inventory in the ocean and better characterize $\mathrm{Pu}$ accumulation in general.

The ${ }^{239+240} \mathrm{Pu}$ inventory in the water column is calculated by integrating the activity measured at each depth ${ }^{61}$. Here, we made an attempt to quantify the stoichiometry between the ${ }^{239+240} \mathrm{Pu}$ inventory and depth via analysis of a large number of field data in the Pacific Ocean. The plot of ${ }^{239+240} \mathrm{Pu}$ inventory (y) vs. depth (x) using this extensive dataset is shown in Figure 7 and shows that they are positively correlated. Linear equations describing these data are also shown in Figure 7 for the South Pacific Ocean $\left(y=0.0049 x, R^{2}=0.6675\right)$ and the North Pacific Ocean $\left(y=0.0149 x, R^{2}=0.8548\right)$. Thus, overall, the slopes of the linear equations indicate that the modeled ${ }^{239+240} \mathrm{Pu}$ inventory in the North Pacific Ocean is ca. three times that in the South Pacific Ocean at the same depth. Additionally, we inferred the boundary equations of $y=0.0027 x\left(R^{2}=0.9919\right)$ in the South Pacific Ocean and $y=0.0227 x$ $\left(\mathrm{R}^{2}=0.9960\right)$ in the North Pacific Ocean, respectively. We can therefore roughly calculate the ${ }^{239+240} \mathrm{Pu}$ inventory at a given depth from these relationships. Using a simple first order calculation, the total amount of ${ }^{239+240} \mathrm{Pu}$ is estimated to be $\sim 9.8 \mathrm{PBq}(3.5-10.7 \mathrm{PBq})$ in terms of the average depth $(x=3957 \mathrm{~m})$ and area $\left(\mathrm{S}=1.81 \times 10^{14} \mathrm{~m}^{2}\right)$ of the Pacific Ocean, a value comparable to previous estimates $(8.5-9.06 \mathrm{PBq})^{1,3,12}$. The above well defined relationship between the $\mathrm{Pu}$ inventory and depth allows quickly calculation of the $\mathrm{Pu}$ inventory in the ocean.

\subsection{Quantitative estimate of the Pu-PPG contribution to the Pacific Ocean}

This study confirms that the PPG continuously provides $\mathrm{Pu}$ source to the Pacific Ocean, and excludes other possible sources, such as the Chernobyl and FNA ${ }^{4,12,34}$. The combined field atom ratios of $\mathrm{Pu}$ in the Pacific Ocean were also found to lie between the global fallout and the PPG (Figure 8), suggesting that Pu in the Pacific Ocean originates from both global fallout and the PPG. The Pu-PPG contribution in the Pacific Ocean can be calculated using the following equation ${ }^{62}$ :

$$
(P u)_{K}=(P u)_{P}+(P u)_{G}
$$

where $(P u)$ represents the ${ }^{239+240} \mathrm{Pu}$ activity; the subscripts $P, G$ and $K$ indicate the 
361 PPG, global fallout and the Pacific sample, respectively. The partitioning between $(P u)_{P}$ 362 and $(P u)_{G}$ can be expressed as:

$$
Y=\frac{(P u)_{P}}{(P u)_{G}}
$$

Based on mass balance considerations, equation (3) can be deduced from equations (1) and (2) as:

$$
Y=\frac{(P u)_{P}}{(P u)_{G}}=\frac{\left(R_{G}-R_{K}\right)\left(1+3.674 R_{P}\right)}{\left(R_{K}-R_{P}\right)\left(1+3.674 R_{G}\right)}
$$

where $R$ represents the ${ }^{240} \mathrm{Pu} /{ }^{239} \mathrm{Pu}$ atom ratio, and the coefficient 3.674 is a conversion factor between the activity ratio and atom ratio of ${ }^{240} \mathrm{Pu} /{ }^{239} \mathrm{Pu}$. while the Pu-PPG contribution to the Pacific sample can be expressed as:

$$
\frac{(P u)_{P}}{(P u)_{K}}=\frac{Y}{1+Y}
$$

In the calculation, $R_{K}$ is the ${ }^{240} \mathrm{Pu} /{ }^{239} \mathrm{Pu}$ atom ratio in the Pacific sample, $R_{G}$ averages $0.180 \pm 0.014^{63}$ and $R_{P}$ averages $0.330 \pm 0.030^{11}$. Plutonium from the PPG was estimated to average $70.7 \pm 12.9 \%$ and $29.0 \pm 4.2 \%$ of surface seawater in the North Pacific and South Pacific, respectively. Overall, the Pu-PPG contributed $69.6 \pm 14.4 \%$ to the Pacific Ocean surface seawater, values is slightly higher than the results in the Pacific's marginal seas, e.g., the East China Sea $(\sim 36 \% \text { : })^{64}$, South China Sea $(\sim 42 \%)^{4,30}$ and Japan Sea $(\sim 33 \%)^{65}$. The spatial distribution of the PPG contribution to surface seawater in the Pacific Ocean is plotted in Figure 9, showing a high PPG contribution in the transport pathway, e.g., the Kuroshio. The Pu-PPG contribution to the North Pacific was significantly higher (by a factor of 3) than that to the South Pacific. A higher Pu-PPG fraction was determined in the intersection zone between the Kuroshio and the Oyashio ${ }^{66}$, a finding potentially related to the continuous PPG input via the NEC and Kuroshio ${ }^{4,12}$.

\subsection{Pu transport pathway in the Pacific Ocean and implication for ocean circulation}

The ${ }^{240} \mathrm{Pu} /{ }^{239} \mathrm{Pu}$ atom ratios $(0.192-0.279)$ of surface and deep water in the Pacific Ocean were higher than those of global fallout (average $=0.180 \pm 0.014$ ) ${ }^{63}$, suggesting that this ocean region must have received Pu from the Marshall Islands PPG characterized by a 
high ${ }^{240} \mathrm{Pu} /{ }^{239} \mathrm{Pu}$ atom ratio (range $=0.30-0.36$ ) ${ }^{11}$. The Pu input from the PPG to the Pacific Ocean can be divided into two periods. During the period 1952-1958, large-scale US nuclear tests were conducted at the Marshall Islands PPG including the Enewetak and Bikini Atolls with high-energy thermonuclear detonations ${ }^{10}$. The Mike test at the Enewetak Atoll in 1952 and the Bravo test at the Bikini Atoll in 1954 yielded a fission of $15 \mathrm{Mt}$ and $15 \mathrm{Mt}$, respectively ${ }^{60}$. They were also the only ones characterized significantly high ${ }^{240} \mathrm{Pu} /{ }^{239} \mathrm{Pu}$ atom ratios ${ }^{60}$. Depending upon local wind conditions and atmospheric deposition patterns ${ }^{67}, 50 \%$ of two high-energy thermonuclear detonations was deposited preferentially within the vicinity of the test sites (close-in tropospheric fallout) ${ }^{7,33,60}$. It is estimated that ca. $60 \%$ of the ${ }^{239+240} \mathrm{Pu}$ inventory in the North Pacific originated from the $\mathrm{PPG}^{1}$. Even in the subarctic zone far away from the PPG, high ${ }^{240} \mathrm{Pu} /{ }^{239} \mathrm{Pu}$ atom ratios $(0.247 \pm 0.007, \mathrm{n}=7)$ were observed in $1988^{29,33}$.

Plutonium deposited in the Pacific Ocean is further transported via oceanic current circulation. For example, Pu from the PPG circulates in the subarctic zone via the Alaska stream, and Oyashio and Alaska currents ${ }^{68}$. Thus, after banning of US nuclear weapons testing in the Marshall Islands, Pu from the PPG was mainly dispersed throughout the Pacific Ocean by circulation currents (e.g., NEC and Kuroshio), resulting in the ubiquitous $\mathrm{Pu}-\mathrm{PPG}$ signature in this region. The NEC, originating approximately from the PPG, transported the high activity of ${ }^{239+240} \mathrm{Pu}$ westward and subsequently fed into its northward and southward bifurcations off the Philippines, namely, the Kuroshio Current and North Equatorial Countercurrent (NECC). In the North Pacific, Pu from the PPG is transported northwestwardly by the Kuroshio. This high ${ }^{240} \mathrm{Pu} /{ }^{239} \mathrm{Pu}$ "stream" along the NEC-Kuroshio was evident when compared with ${ }^{240} \mathrm{Pu} /{ }^{239} \mathrm{Pu}$ atom ratios outside this pathway in the western Pacific Ocean ${ }^{12,30}$ and its adjacent marginal seas ${ }^{4,30,65,69-72}$. Persistently high ${ }^{240} \mathrm{Pu} /{ }^{239} \mathrm{Pu}$ atom ratios $(0.224-0.279$, average $=0.251 \pm 0.018, \mathrm{n}=14)$ were observed in the inter-frontal zone $\left(30^{\circ}-40^{\circ} \mathrm{N}, 140^{\circ}-170^{\circ} \mathrm{E}\right)$ between the Kuroshio and the Oyashio during the period 1988-2014,12,29,32-33,66; this is potentially related to the continuous Pu-PPG supply via the NEC-Kuroshio. Correspondingly, high ${ }^{239+240} \mathrm{Pu}$ activities and inventories were also observed in this region. Indeed, this region is also the formation zone of Subtropical Mode Water (STMW) ${ }^{20-21,73}$, which penetrates at ca. 300-500 m depth ${ }^{22}$. The formation and circulation of the STMW and Central Mode Water (CMW) has been in detail 
418 described in elsewhere ${ }^{22}$. STMW mainly comprises Oyashio and Kuroshio water, 419 accounting for $\sim 45 \%$ and $\sim 55 \%$, respectively ${ }^{66,74}$. Thus, high ${ }^{240} \mathrm{Pu} /{ }^{239} \mathrm{Pu}$ atom ratios of 420 surface seawater could be transported to outside of the Kuroshio zone by spreading and 421 subduction of STMW. And then, the STMW spreads near the subtropical front via 422 advection over the Kuroshio recirculation region ${ }^{75-77}$. Then, the Pu signature from the PPG 423 is continuously transported into the CMW formation area by the Kuroshio extension and 424 North Pacific Current ${ }^{78}$. In general, the CMW firstly spreads eastward along the North 425 Pacific Current, turns southward and then westward ${ }^{22}$. Plutonium from the PPG is further 426 transported to the tropical zone by CMW spreading and subduction. In the South Pacific 427 Ocean, Pu from the PPG is transported by the NECC and South Equatorial Current. 428 Therefore, $\mathrm{Pu}$ from the PPG is also a useful potential tracer for oceanic circulation in the 429 Pacific Ocean.

\section{Conclusions}

${ }^{240} \mathrm{Pu} /{ }^{239} \mathrm{Pu}$ atomic ratios in both deep and surface water were determined to be 434 the Pacific Ocean. The horizontal distribution of ${ }^{240} \mathrm{Pu} /{ }^{239} \mathrm{Pu}$ atomic ratios showed a gradual 435 decrease in the direction of the subarctic gyre, declining along the Kuroshio from the 436 eastern Philippines to southern Japan. The ${ }^{239+240} \mathrm{Pu}$ activities of surface seawater in the 437 Pacific Ocean were determined to be $0.2-43.5 \mathrm{mBq} \mathrm{m}^{-3}$, showing an increase with 438 increasing latitude. The present study confirms the non-global Pu from the PPG by 439 comparing $\mathrm{Pu}$ isotopic compositions between the zones within and outside the circulation 440 current region. Plutonium sources are constrained by the PPG and global fallout in the 441 Pacific Ocean. The present study further revealed that the PPG contributed on average 70.7 $442 \pm 12.9 \%$ and $29.0 \pm 4.2 \%$ of Pu to the North Pacific and the South Pacific, respectively. at $300-900 \mathrm{~m}$, averaging $608 \pm 137 \mathrm{~m}$. The ${ }^{239+240} \mathrm{Pu}$ inventory in the Pacific Ocean has a varied vertical structure, namely, the percent ${ }^{239+240} \mathrm{Pu}$ inventory at $0-1000 \mathrm{~m}$ and $0-3000 \mathrm{~m}$ accounted for $43.5 \pm 9.0 \%$ and $75.1 \pm 12.0 \%$ of the total, respectively. Additionally, the Pacific Ocean is mainly impacted by PPG Pu through early atmospheric deposition and subsequent ocean circulation currents. We established the transport pathway of $\mathrm{Pu}$ from the 
PPG in the Pacific Ocean and demonstrated that Pu was an excellent tracer of oceanic circulation. Finally, via this new compilation of $\mathrm{Pu}$ isotopic compositions in the Pacific Ocean, we have established a background for the coming Pu studies associated with the nuclear sewage from the FNA discharged into the Pacific Ocean.

Additional work includes the understanding $\mathrm{Pu}$ biogeochemistry and the fate of this element in the Pacific Ocean. We conclude that Pu from the PPG serves as a promising tracer that could be widely used to study ocean circulation currents in the Pacific Ocean. Certainly, $\mathrm{Pu}$ isotopic composition in the circulation currents, e.g., the NEC and CMW, needs to be further investigated. Plutonium isotopes need to be continuously monitored in lagoonal seawater discharges, sediment and marine organisms in the PPG to accurately evaluate Pu's ecological impact. Finally, future developments aimed at increasing the sensitivity of different synchrotron radiation (SR)-X-ray microbeams and mass spectrometric techniques will allow improved characterization of the distribution and speciation of $\mathrm{Pu}$ in the Pacific Ocean.

\section{Acknowledgements} (42076038), the Natural Science Foundation of Guangdong Province (2021A1515011886),

\section{Author information}

* Corresponding author:

$$
\text { E-mail:wujw@stu.edu.cn (J.W.Wu) }
$$

wangcui@tio.org.cn

This study was supported by the National Natural Science Foundation of China Key Special Project for Introduced Talents Team of Southern Marine Science and Engineering Guangdong Laboratory (Guangzhou) (GML2019ZD0606), STU Scientific Research Foundation for Talents (NTF18011), Natural Science Foundation of Guangdong Province (2019A1515010611), Innovation and Entrepreneurship Project of Shantou (2021112176541391), Marine Economic Development Project of Guangdong Province (GDNRC[2020]050).

\section{Author Contributions}

Junwen Wu: Conceptualization, Funding acquisition, Writing-original draft \& editing. Jisheng Chen: Methodology-collecting the data. Cui Wang: Writing-review \& 
editing. Zhaoyong Zheng: Review \& editing. Liang Wang: Review \& editing.

\section{Declaration of competing interest}

The authors declare that they have no known competing financial interests or personal relationships that could have appeared to influence the work reported in this paper.

Publisher's note: Springer Nature remains neutral with regard to jurisdictional claims in published maps and institutional affiliations.

Open Access: This article is licensed under a Creative Commons Attribution 4.0 International License, which permits use, sharing, adaptation, distribution and reproduction in any medium or format, as long as you give appropriate credit to the original author(s) and the source, provide a link to the Creative Commons license, and indicate if changes were made. The images or other third-party material in this article are include in the article's Creative Commons license, unless indicated otherwise in a credit line to the material. If material is not included in the article's Creative Commons license and your intended use is not permitted by statutory regulation or exceeds the permitted use, you will need to obtain permission directly from the copyright holder. To view a copy of this license, visit http://creativecommons.org/licenses/by/4.0/.

\section{References}

1 Bowen, V.T., Noshkin, V.E., Livingston, H.D., Volchok, H.L., 1980. Fallout radionuclides in the Pacific Ocean: vertical and horizontal distribution, largely from GEOSESC station. Earth Planet. Sci. Lett. 49, 411-434.

2 Sholkovitz, E.R., 1983. The geochemistry of plutonium in fresh and marine water environments. Earth Sci. Rev. 19, 95-161.

3 Hamilton, T.F., 2004. Linking legacies of the Cold War to arrival of anthropogenic radionuclides in the oceans through th 20th century. In : Livingston, H.D. (Ed.), Radioactivity in the Environment. Marine Radioactivity 6. Elsevier Ltd, Oxford, pp. 2378.

4 Wu, J.W., Dai, M.H., Xu, Y., Zheng, J., 2018. Sources and accumulation of plutonium in a large Western Pacific marginal sea: The South China Sea. Sci. Total Environ. 610-611, 200-211.

5 Warneke, T., Croudace, I.W., Warwick, P.E., Taylor, R.N., 2002. A new ground-level 
fallout record of uranium and plutonium isotopes for northern temperate latitudes. Earth Planet. Sci. Lett. 203, 1047-1057.

$6 \mathrm{Wu}$, J.W., Sun, J., Xiao, X.Y., 2020. An overview of current knowledge concerning the inventory and sources of plutonium in the China Seas. Mar. Pollut. Bull. 150, 110599, https://doi.org/10.1016/j.marpolbul.2019.110599.

7 Lindahl, P., Asami, R., Iryu, Y., Worsfold, P., Keith-Roach, M., Choi, M.S., 2011. Sources of plutonium to the tropical Northwest Pacific Ocean (1943-1999) identified using a natural coral archive. Geochim. Cosmochim. Acta 75, 1346-1356.

8 Eigl, R., Srncik, M., Steier, P., Wallner, G., 2013. ${ }^{236} \mathrm{U} /{ }^{238} \mathrm{U}$ and ${ }^{240} \mathrm{Pu} /{ }^{239} \mathrm{Pu}$ isotopic ratio in small (2 L) sea and river water samples. J. Environ. Radioact. 116, 54-58.

9 Zheng, J., Yamada, M., 2006. Plutonium isotopes in settling particles: transport and scavenging of $\mathrm{Pu}$ in the western Northwest Pacific. Environ. Sci. Technol. 40, 41034108.

10 Buesseler, K.O., 1997. The isotopic signature of fallout plutonium in the North Pacific. J. Environ. Radioact. 36, 69-83.

11 Muramatsu, Y., Hamilton, T., Uchida, S., Tagami, K., Yoshida, S., Robison, W., 2001. Measurement of ${ }^{240} \mathrm{Pu} /{ }^{239} \mathrm{Pu}$ isotopic rations in the soil from the Marshall Islands using ICP-MS. Sci. Total Environ. 278, 151-159.

12 Wu, J.W., Dai, M.H., Xu, Y., Zheng, J., 2019. Plutonium in the western North Pacific: transport along the Kuroshio and implication for the impact of the Fukushima Daiichi Nuclear Power Plant accident. Chem. Geol. 511, 256-264.

13 Povinec, P.P., Hirose, K., Honda, T., Ito, T., Scott, E.M., Tagawa, O., 2004. Spatial distribution of ${ }^{3} \mathrm{H},{ }^{90} \mathrm{Sr},{ }^{137} \mathrm{Cs}$ and ${ }^{239,240} \mathrm{Pu}$ in surface waters of the Pacific and Indian Oceans-GLOMARD database. J. Environ. Radioact. 76, 113-137.

14 Kinoshita, N., Sumi, T., Takimoto, K., Nagaoka, M., Yokoyama, A., Nakanishi, T., 2011. Anthropogenic Pu distribution in Tropical East Pacific. Sci. Total Environ. 409, 1889-1899.

15 Sakaguchi, A., Kadokura, A., Steier, P., Tanaka, K., Takahashi, Y., Chiga, H., Matsushima, A., Nakashima, S., Onda, Y., 2012. Isotopic determination of U, Pu and Cs in environmental waters following the Fukushima Daiichi Nuclear Power Plant accident. Geochem. J. 46, 355-360. 
16 Bu, W.T., Zheng, J., Aono, T., Wu, J.W., Tagami, K., Uchida, S., Guo, Q.J., Yamada, M., 2015. $\mathrm{Pu}$ distribution in seawater in the near coastal area off Fukushima after the Fukushima Daiichi Nuclear Power Plant accident. J. Nucl. Radiochem. Sci. 15, 1-6.

17 Oikawa, S., Watabe, T., Takata, H., 2015. Distributions of Pu isotopes in seawater and bottom sediments in the coast of the Japanese archipelago before and soon after the Fukushima Dai-ichi nuclear power station accident. J. Environ. Radioact. 142, 113-123. 18 Hain, K., Faestermann, T., Fimiani, L., Golser, R., Gomez-Guzman, J.M., Korschinek, G., Kortmann, F., von Gostomski, C.L., Ludwig, P., Steier, P., Tazoe, H., Yamada, M., 2017. Plutonium isotopes $\left({ }^{239-241} \mathrm{Pu}\right)$ dissolved in Pacific Ocean waters detected by Accelerator Mass Spectrometry: no effects of the Fukushima accident observed. Environ. Sci. Technol. 51, 2031-2037.

19 Casacuberta, N., Christl, M., Buesseler, K.O., Lau, Y.S., Vockenhuber, C., Castrillejo, M., Synal, H.A., Masque, P., 2017. Potential release of ${ }^{129} \mathrm{I},{ }^{236} \mathrm{U}$, and $\mathrm{Pu}$ isotopes from the Fukushima Dai-ichi nuclear power plants to the ocean from 2013 to 2015. Environ. Sci. Technol. 51, 9826-9835.

20 Kawabe, M., Fujio, S., 2010. Pacific ocean circulation based on observation. J. Oceanogr. 66, 389-403.

21 Talley, L.D., Pickard, G.L., Emery, W.J., Swift, J.H., 2011. Physical oceanography and introduction. Elsevier Ltd.

22 Kumamoto, Y., Aoyama, M., Hamajima, Y., Aono, T., Kouketsu, S., Murata, A., Kawano, T., 2014. Southward spreading of the Fukushima-derived radiocesium across the Kuroshio extension in the North Pacific. Sci. Rep. 4, 4276. doi: 10.1038/srep04276.

23 Hu, D.X., Wu, L.X., Cai, W.J., Gupta, A.S., Ganachaud, A., Qiu, B., Gordon, A.L., Lin, X.P., Chen, Z.H., Hu, S.J., Wang, G.J., Wang, Q.Y., Sprintall, J., Qu, T.D., Kashino, Y.J., Wang, F., Kessler, W.S., 2015. Pacific western boundary currents and their roles in climate. Nature 522, 299-308.

24 Macdonald, A.M., Yoshida, S., Pike, S.M., Buesseler, K.O., Rypina, I.I., Jayne, S.R., Rossi, V., Kenyon, J., Drysdale, J.A., 2020. A Fukushima tracer perspective on four years of North Pacific mode water evolution. Deep-Sea Res. PT. I 166, doi: 10.1016/j.dsr.2020.103379.

25 Sverdrup, H.U., Johnson, M.W., Fleming, R.H., 1942. The Oceans: their physics, 
chemistry and general biology. Prentice-Hall Inc., Englewood Cliffs, NJ, 1057 pp.

26 Qu, T.D., Lukas, R., 2003. The bifurcation of the North Equatorial Current in the Pacific. J. Phys. Oceanogr. 33, 5-18.

27 Wang, G., Xie, S.P., Qu, T., Huang, R.X., 2011. Deep South China Sea circulation. Geophys. Res. Lett. 38, L05601, doi: 10.1029/2010GL046626.

28 Stramma, L., Peterson, R.G., Tomczak, M., 1995. The South Pacific Current. J. Phys. Oceanogr. 25, 77-91.

29 Nagaya, Y., Nakamura, K., 1993. Distributions and mass-balance of ${ }^{239,240} \mathrm{Pu}$ and ${ }^{137} \mathrm{Cs}$ in the Northern North Pacific. Deep Ocean Circulation, Physical and Chemical Aspects edited by Teramoto, T. 157-167.

30 Yamada, M., Zheng, J., Wang, Z.L., $2006 .{ }^{137} \mathrm{Cs},{ }^{239+240} \mathrm{Pu}$ and ${ }^{240} \mathrm{Pu} /{ }^{239} \mathrm{Pu}$ atom ratios in the surface waters of the Western North Pacific Ocean, Eastern Indian Ocean and their adjacent seas. Sci. Total Environ. 366, 242-252.

31 Yamada, M., Zheng, J., 2012. ${ }^{239} \mathrm{Pu}$ and ${ }^{240} \mathrm{Pu}$ inventories and ${ }^{240} \mathrm{Pu} /{ }^{239} \mathrm{Pu}$ atom ratios in the equatorial Pacific Ocean water column. Sci. Total Environ. 430, 20-27.

32 Men, W., Zheng, J., Wang, H., Ni, Y.Y., Kumamoto, Y., Yamada, M., Uchida, S., 2019.

$\mathrm{Pu}$ isotopes in the seawater off Fukushima Daiichi Nuclear Power Plant site within two months after the severe nuclear accident. Environ. Pollut. 246, 303-310.

33 Yamada, M., Zheng, J., 2020. ${ }^{240} \mathrm{Pu} /{ }^{239} \mathrm{Pu}$ atom ratios in water columns from the North Pacific Ocean and Bering Sea: Transport of Pacific Proving Grounds-derived Pu by ocean currents, Sci. Total Environ. 718. https://doi.org/10.1016/j.scitotenv.2020.137362.

34 Kim, C.K., Kim, C.S., Chang, B.U., Choi, S.W., Chung, C.S., Hong, G.H., Hirose, K., Igarashi, Y., 2004. Plutonium isotopes in seas around the Korean Peninsula. Sci. Total Environ. 318, 197-209.

35 Zheng, J., Tagami, K., Watanabe, Y., Uchida, S., Aono, T., Ishii, N., Yoshida, S., Kubota, Y., Fuma, S., Ihara, S., 2012. Isotopic evidence of plutonium release into the environment from the Fukushima DNPP accident. Sci. Rep. 2, 304, doi:10.1038/srep00304.

36 Bu, W.T., Zheng, J., Guo, Q.J., Aono, T., Tagami, K., Uchida, S., Tazoe, H., Yamada, M., 2014a. Ultra-trace plutonium determination in small volume seawater by sector field inductively coupled plasma mass spectrometry with application to Fukushima seawater 
samples. J. Chromatogr. A 1337, 171-178.

37 Bu, W.T., Zheng, J., Guo, Q.J., Aono, T., Tazoe, H., Tagami, K., 2014b. A method of measurement of ${ }^{239} \mathrm{Pu},{ }^{240} \mathrm{Pu},{ }^{241} \mathrm{Pu}$ in high $\mathrm{U}$ content marine sediments by sector field ICP-MS and its application to Fukushima sediment samples. Environ. Sci. Technol. 48, $534-541$.

38 Zheng, J., Yamada, M., Wu, F.C., Liao, H.Q., 2009. Characterization of Pu concentration and its isotopic composition in soils of Gansu in northwestern China. J. Environ. Radioact. 100, 71-75.

39 Bu, W.T., Fukuda, M., Zheng, J., Aono, T., Ishimaru, T., Kanda, J., Yang, G.S., Tagami, K., Uchida, S., Guo, Q.J., Yamada, M., 2014c. Release of Pu isotopes from the Fukushima Daiichi Nuclear Power Plant Accident to the marine environment was negligible. Environ. Sci. Technol. 48, 9070-9078.

$40 \mathrm{Wu}$, J.W., 2019. Isotopic composition and source of plutonium in the Qinghai-Tibet Plateau frozen soils. Sci. Rep. 9, 7861, https://doi.org/10.1038/s41598-019-44391-0.

41 Nakanishi, T., Satoh, M., Takei, M., Ishikawa, A., Murata, M., Dairyoh, M., Higuchi, S., 1990. Successive determination of ${ }^{210} \mathrm{~Pb},{ }^{210} \mathrm{Po},{ }^{226} \mathrm{Ra},{ }^{228} \mathrm{Ra}$ and selected actinides in seawater and sea sediment. J. Radioanal. Nucl. Chem. 138, 321-330.

42 Povinec, P. P., Aarkrog, A., Buesseler, K.O., Delfanti, R., Hirose, K., Hong, G.H., Ito, T., Livingston, H.D., Nies, H., Noshkin, V.E., Shima, S., Togawa, O., $2005 .{ }^{90} \mathrm{Sr},{ }^{137} \mathrm{Cs}$ and ${ }^{239,240} \mathrm{Pu}$ concentration surface water time series in the Pacific and Indian OceansWOMARS results. J. Environ. Radioact. 81, 63-87.

43 Lettner, H., Bossew, P., Hubmer, A.K., 2000. Spatial variability of fallout caesium-137 in Austrian alpine regions. J. Environ. Radioact. 47, 71-82.

44 Joseph, A.B., Gustafson, P.F., Russell, I.R., Schuert, E.A., Volchok, H.L., Tamplin, A., 1971. Sources of radioactivity and their characteristics-Radioactivity in the Marine Environment. Washington: National Academy Sciences, 6-41.

45 Adams, C.E., Farlow, N.H., Schell, W.R., 1960. The compositions, structures and origins of radioactive fallout particles. Geochim. Cosmochim, Acta 18, 42-56.

46 Shiozaki, T., Furyua, K., Kodama, T., Kitajima, S., Takeda, S., Takemura, T., Kanda, J., 2010. New estimation of $\mathrm{N}_{2}$ fixation in the western and central Pacific Ocean and its marginal seas. Global Biogeochem. Cy. 24, GB1015, doi: 10.1029/2009GB003620. 
47 Bonnet, S., Berthelot, H., Kubo, K.T., Fawcett, S., Rahav, E., L’Helguen, S., Frank, I.B., 2016. Dynamics of $\mathrm{N}_{2}$ fixation and fate of diazotroph-derived nitrogen in a low-nutrient, low-chlorophyll ecosystem: results from the VAHINE mesocosm experiment (New Caledonia). Biogeosciences 13, 2653-2673.

48 Chen, Y.L.L., Tuo, S.H., Chen, H.Y., 2011. Co-occurrence and transfer of fixed nitrogen from Trichodesmium spp. To diatoms in the low-latitude Kuroshio Current in the NW Pacific. Mar. Ecol. Prog. Ser. 421, 25-38.

49 Chen, Y.L.L., Chen, H.Y., Tuo, S.H., Ohki, K., 2008. Seasonal dynamics of new production from Trichodesmium $\mathrm{N}_{2}$ fixation and nitrate uptake in the upstream Kuroshio and South China Sea. Limnol. Ocanogr. 53, 1705-1721.

50 Kitajima, S., Furuya, K., Hashihama, F., Takeda, S., 2009. Latitudinal distribution of diazotrophs and their nitrogen fixation in the tropical and subtropical western North Pacific. Limnol. Oceanogr. 54, 537-547.

51 Nakajima, K., 1973. Suspended particulate matter in the western North Pacific Ocean. Hokkaido University, Sapporo, pp 43.

52 Buesseler, K.O., Charette, M.A., Pike, S.M., Henderson, P.B., Kipp, L.E., 2018. Lingering radioactivity at the Bikini and Enewetak Atolls. Sci. Total Environ., 621, 1185-1198.

53 Harley, J.H., 1980. Plutonium in the environment-a review. J. Radiat. Res. 21, 83-104.

54 Perkins, R.W., Thomas, C.W., 1980. Worldwide fallout. In Transuranic Elements in the Environment, ed. W.C. Hanson, pp. 53-82. Tech. Inf. Center US Department of Energy. 55 Yamada, M., Zheng, J., Wang, Z.L., 2007. ${ }^{240} \mathrm{Pu} /{ }^{239} \mathrm{Pu}$ atom ratios in seawater from Sagami Bay, Western Northwest Pacific Ocean: sources and scavenging. J. Environ. Radioact. 98, 274-284.

56 Letelier, R.M., White, A.E., Bidigare, R.R., Barone, B., Church, M.J., Karl, D.M., 2017. Light absorption by phytoplankton in the North Pacific Subtropical Gyre. Limnol. Oceanogr. 62, 1526-1540.

57 Zhang, Y.W., Kieft, B., Hobson, B.W., Ryan, J.P., Barone, B., Preston, C.M., Roman, B., Raanan, B.Y., Marin III, R., O’Reilly, T.C., Rueda, C.A., Parget, D., Yamahara, K.M., Poulos, S., Romano, A., Foreman, G., Ramm, H., Wilson, S.T., DeLong, E.F., Karl, D.M., Birch, J.M., Bellingham, J.G., Scholin, C.A., 2020. Autonomous tracking and sampling 
of the deep Chlorophyll maximum layer in an open-ocean eddy by a long-range autonomous underwater vehicle. IEEE J. Oceanic Eng. 45, 1308-1321.

58 Falkowski, P.G., Biscaye, P.E., Sancetta, C., 1994. The lateral flux of biogenic particles from the eastern North American continental margin to the North Atlantic Ocean. DeepSea Res. II 41, 583-601.

59 Liu, J.G., Clift, P.D., Yan, W., Chen, Z., Chen, H., Xiang, R., Wang, D.X., 2014. Modern transport and deposition of settling particles in the northern South China Sea: Sediment trap evidence adjacent to Xisha Trough. Deep-Sea Res. I 93, 145-155.

60 UNSCEAR Report: Sources and effects of ionizing radiation. United Nations scientific committee on the effects of atomic radiation exposures to the public from man-made sources of radiation; United Nations, New York, 2000.

61 Ito, T., Aramaki, T., Kitamura, T., et al., 2003. Anthropogenic radionuclides in the Japan Sea: their distributions and transport processes. J. Environ. Radioact. 68, 249267.

62 Krey, P. W., 1976. Remote Pu contamination and total inventories from Rocky Flats. Health Phys. 30, 209-214.

63 Kelley, J.M., Bond, L.A., Beasley, T.M., 1999. Global distribution of Pu isotopes and ${ }^{237} \mathrm{~Np}$. Sci. Total Environ. 237-238, 483-500.

$64 \mathrm{Wu}$, J.W., 2018. Sources and scavenging of plutonium in the East China Sea. Mar. Pollut. Bull. 135, 808-818.

65 Yamada, M., Zheng, J., 2008. Determination of ${ }^{240} \mathrm{Pu} /{ }^{239} \mathrm{Pu}$ atom ratio in coastal surface seawaters from the western North Pacific Ocean and Japan Sea. Appl. Radiat. Isot. 66, 103-107.

66 Yasuda, I., Okuda, K., Shimizu, Y., 1996. Distribution and modification of North Pacific Intermediate Water in the Kuroshio-Oyashio interfrontal zone. J. Phys. Oceanogr. 26, 448-465.

67 Machta, L., List, R.J., Hubert, L.F., 1956. World-wide travel of atomic debris. Science $124,474-477$.

68 Tsumune, D., Aoyama, M., Hirose, K., 2003. Numerical simulation of ${ }^{137} \mathrm{Cs}$ and ${ }^{239,240} \mathrm{Pu}$ concentrations by an ocean general circulation model. J. Environ. Radioact. 69, 61-84. 69 Kang, D.J., Chung, C.S., Kim, S.H., Kim, K.R., Hong, G.H., 1997. Distribution of ${ }^{137}$ Cs 
and ${ }^{239,240} \mathrm{Pu}$ in the surface waters of the East Sea (Sea of Japan). Mar. Pollut. Bull. 35, $305-312$

70 Hirose, K., Amano, H., Baxter, M.S., Chaykovskaya, E., Chumichev, V.B., Hong, G.H., Isogai, K., Kim, C.K., Kim, S.H., Miyao, T., Morimoto, T., Nikitin, A., Oda, K., Pettersson, H.B.L., Povinec, P.P., Seto, Y., Tkalin, A., Togawa, O., Veletova, N.K., 1999. Anthropogenic radionuclides in seawater in the East Sea/Japan Sea: Results of the firststage Japanese-Korean-Russian expedition. J. Environ. Radioact. 43, 1-13.

71 Hirose, K., Miyao, T., Aoyama, M., Igarashi, Y., 2002. Plutonium isotopes in the sea of Japan. J. Radioanal. Nucl. Chem. 252, 293-299.

72 Yamada, M., Zheng, J., 2011. Determination of ${ }^{240} \mathrm{Pu} /{ }^{239} \mathrm{Pu}$ atom ratio in seawaters from the East China Sea. Radiat. Prot. Dosim. 146, 311-313.

73 Oka, E., 2009. Seasonal and interannual variation of North Pacific Subtropical Mode Water in 2003-2006. J. Oceanogr. 65, 151-164.

74 Talley, L.D., 1997. North Pacific Intermediate Water transports in the mixed water region. J. Phys. Oceanogr. 27, 1795-1803.

75 Suga, T., Hanawa, K., 1990. The mixed layer climatology in the northwestern part of the North Pacific subtropical gyre and the formation area of Subtropical Mode Water. J. Mar. Res. 48, 543-566.

76 Suga, T., Hanawa, K., 1995. The subtropical mode water circulation in the North Pacific. J. Phys. Oceanogr. 25, 958-970.

77 Aoyama, M., Hirose, K., Igarashi, Y., 2006. Re-construction and updating our understanding on the global weapons test ${ }^{137} \mathrm{Cs}$ fallout. J. Environ. Monit. 8, 431-438.

78 Suga, T., Takei, Y., Hanawa, K., 1997. Thermostad distribution in the North Pacific subtropical gyre: the central mode water and the subtropical mode water. J. Phys. Oceanogr. 27, 140-153.

79 Hirose, K., Aoyama, M., Kim, C.S., Kim, C.K., Povinec, P.P., 2006. Plutonium isotopes in seawater of the North Pacific: effects of close-in fallout. Radioact. Environ. 8, 67-82. 


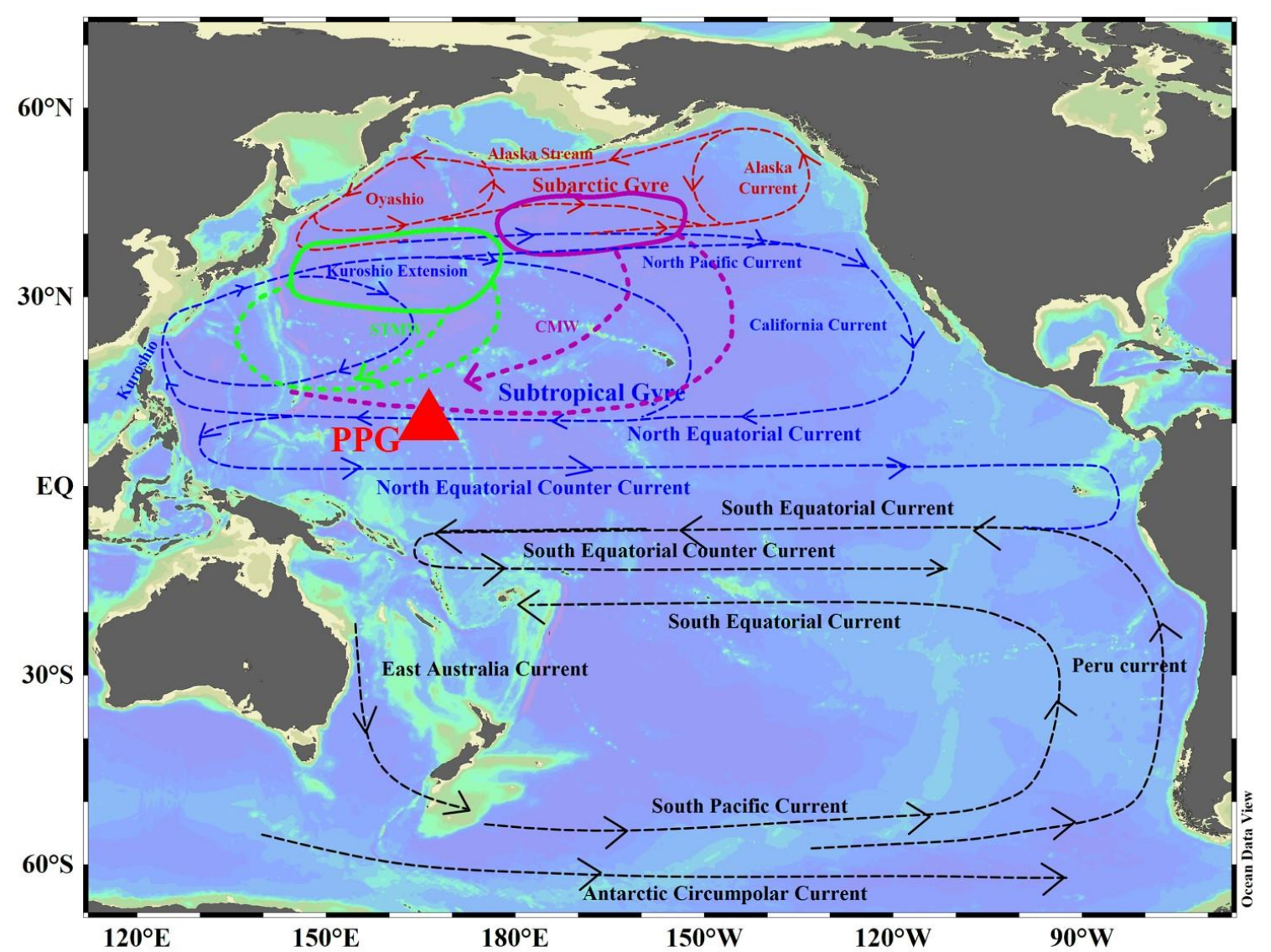

Figure 1. Schematic view of current circulation in the Pacific Ocean. Green solid and dashed ellipses represent the formation and spreading areas, respectively, of Subtropical Mode Water (STMW), respectively. Purple solid and dotted ellipses represent the formation and spreading areas, respectively, of Central Mode Water (CMW). Red and blue dotted

730 lines indicate surface circulation currents of the subtropical and subarctic gyres, 731 respectively. Black dotted lines indicate surface circulation in the South Pacific Ocean. Red 732 triangle marks the Pacific Proving Grounds (PPG). This figure is based on previous 733 publications ${ }^{20,22-24}$. This figure was prepared with the free software Ocean Data View (ODV 734 5.1.2) (Schlitzer, R., Ocean Data View, https://odv.awi.de, 2018) 

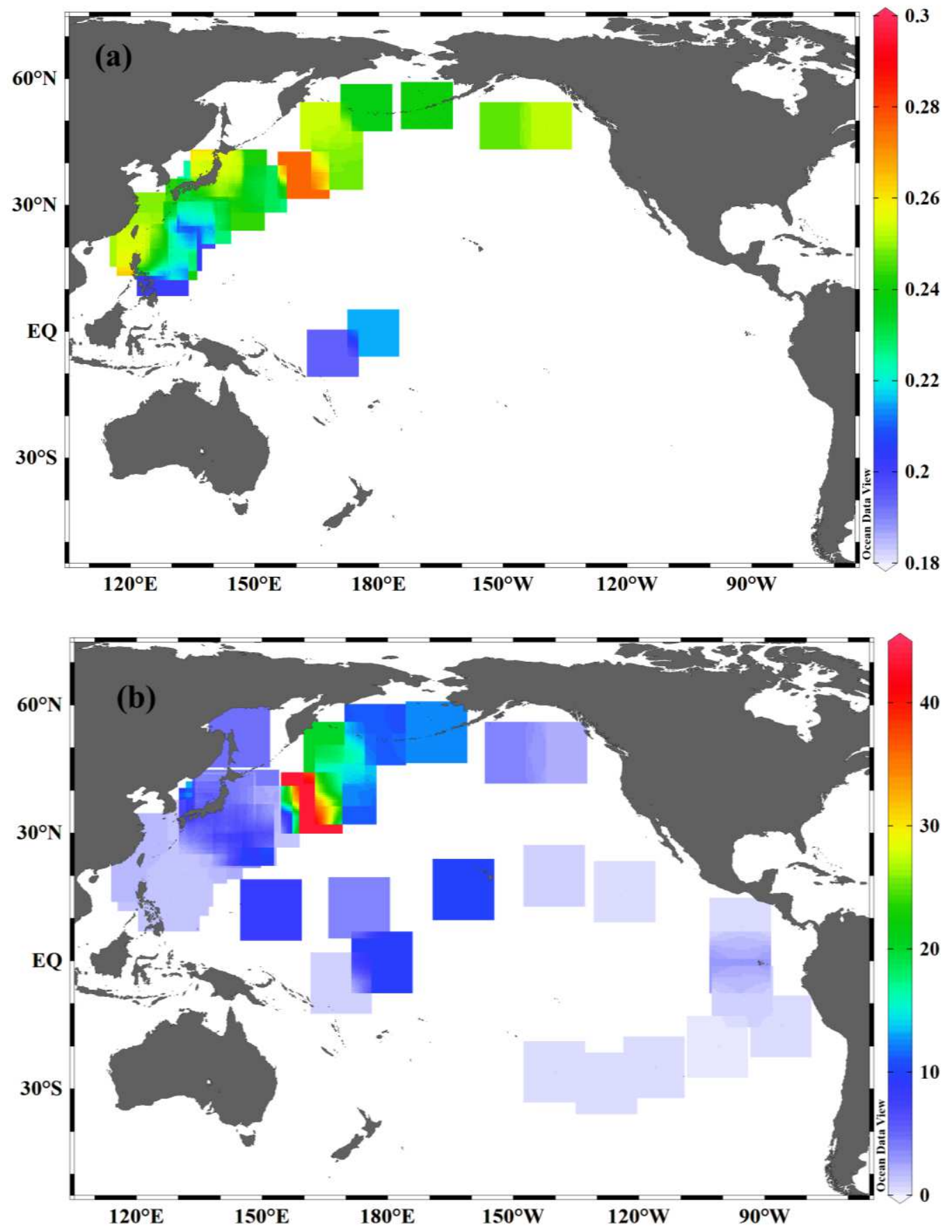

Figure 2. Lateral distribution of the ${ }^{240} \mathrm{Pu} /{ }^{239} \mathrm{Pu}$ atom ratio (a) and ${ }^{239+240} \mathrm{Pu}$ activity (mBq $\left.\mathrm{m}^{-3}\right)(\mathrm{b})$ in the Pacific Ocean. The Pu atom ratios and activities are derived from previous

740 publications ${ }^{4,12,14,29-33,41}$. This figure was prepared with the free software Ocean Data View

741 (ODV 5.1.2) (Schlitzer, R., Ocean Data View, https://odv.awi.de, 2018) 

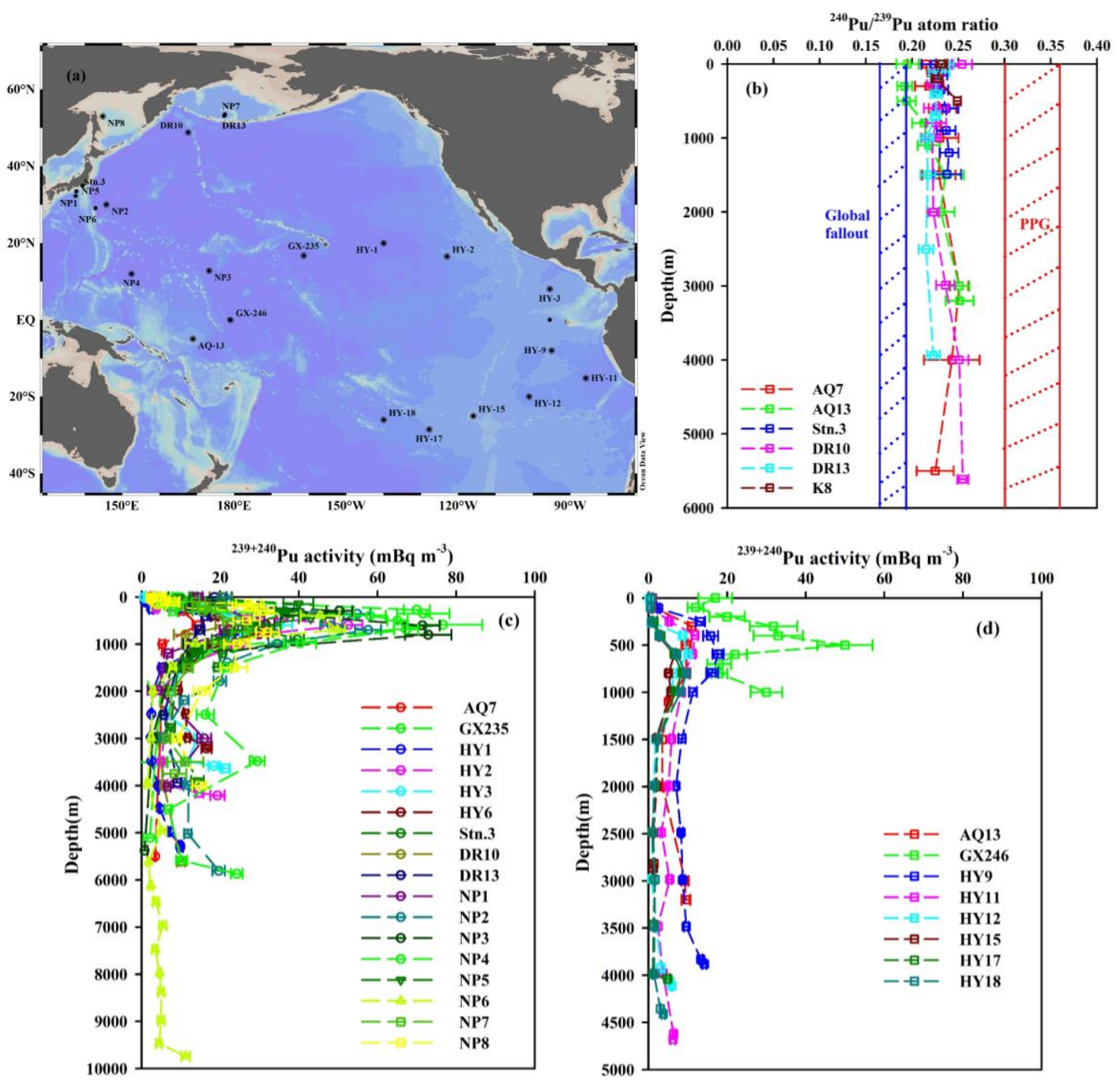

745 Figure 3. Sampling sites for analyzing $\mathrm{Pu}$ in water column from the Pacific Ocean (a) and vertical depth profile of the ${ }^{240} \mathrm{Pu} /{ }^{239} \mathrm{Pu}$ atom ratio (b) and ${ }^{239+240} \mathrm{Pu}$ activity $\left(\mathrm{mBq} \mathrm{m}^{-3}\right)$ at various sampling stations in the North Pacific Ocean (c) and South Pacific Ocean (d). PPG=

748 Pacific Proving Grounds. The $\mathrm{Pu}$ data in the water column are cited from previous 749 publications $1,12,14,29,31,33,41,55$. This figure was prepared with the free software Ocean Data 750 View (ODV 5.1.2) (Schlitzer, R., Ocean Data View, https://odv.awi.de, 2018) (a) and 751 Sigma-Plot professional 10.0 software $(b-d)$. 
Station
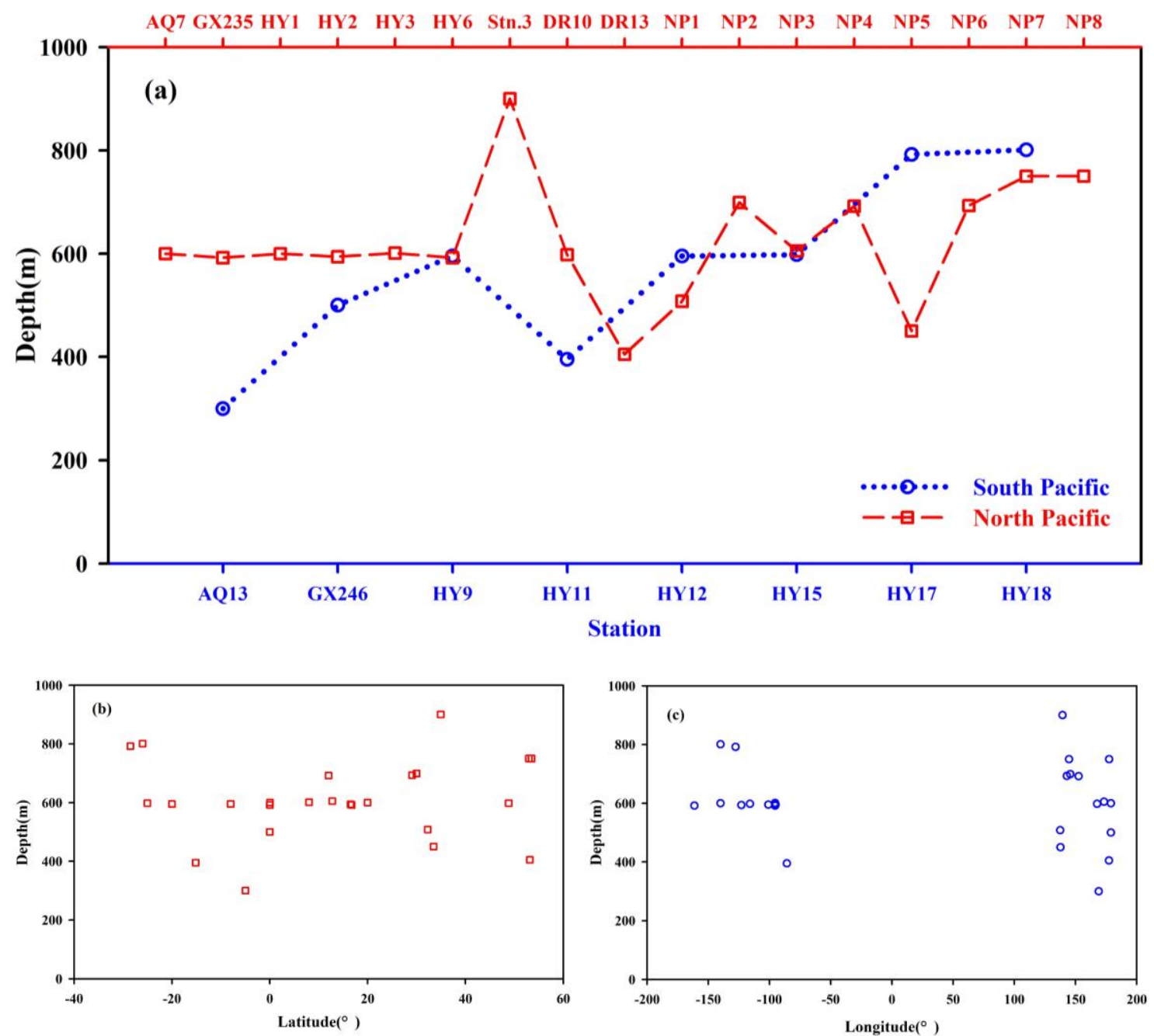

Figure 4. Depth variation of maximum ${ }^{239+240} \mathrm{Pu}$ activity at various stations in the South and North Pacific Ocean (a) and distribution pattern of maxima with latitude (b) and 758 longitude (c). These figures were prepared with Sigma-Plot professional 10.0 software. 

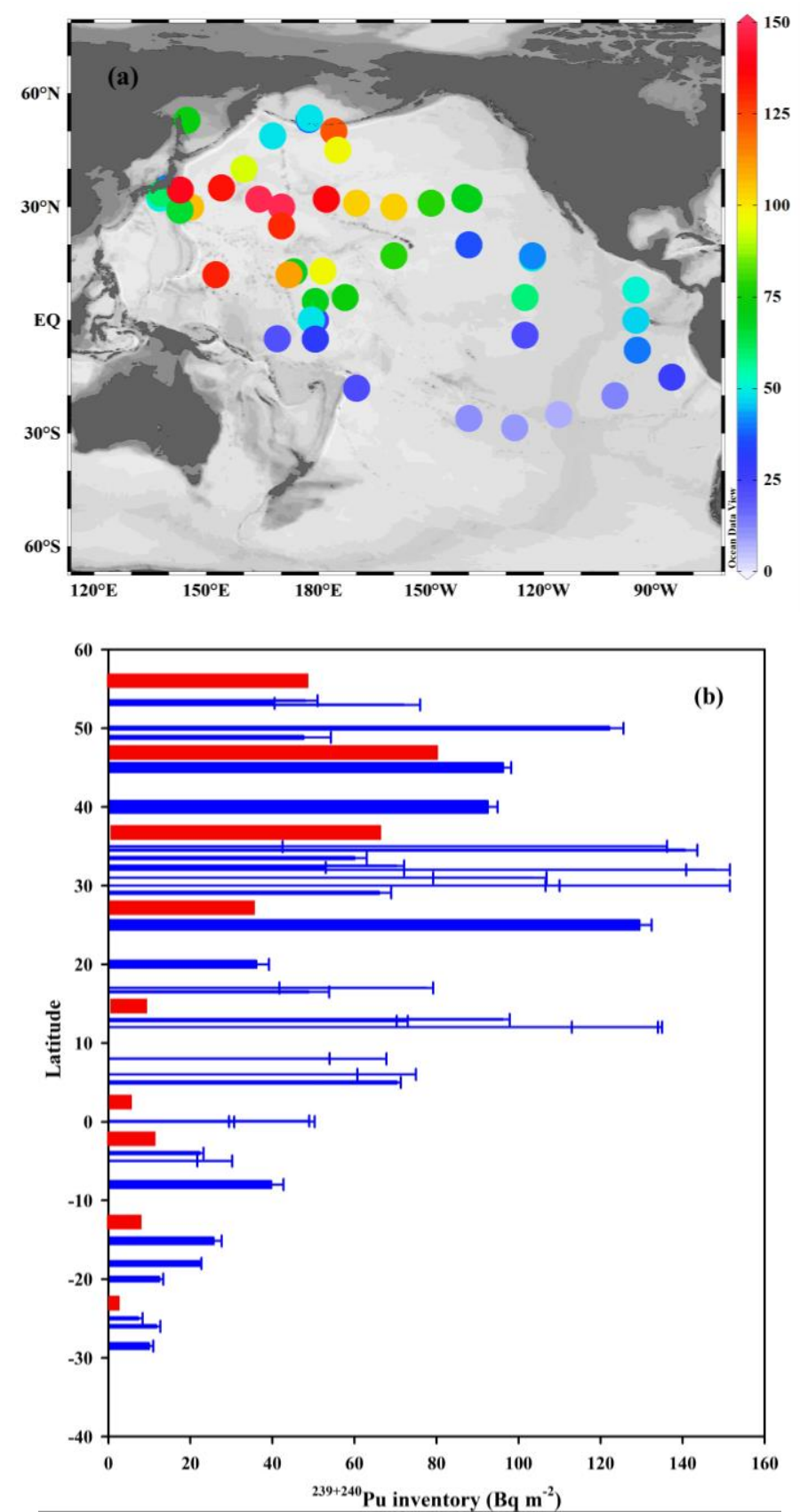

763 Figure 5. Spatial (a) and latitudinal (b) distribution of the ${ }^{239+240} \mathrm{Pu}$ inventory $\left(\mathrm{Bq} \mathrm{m}^{-2}\right)$ in

764 Pacific Ocean seawater. Blue and red bars in (b) represent the ${ }^{239+240} \mathrm{Pu}$ inventory observed 765 in the Pacific Ocean and deposition flux of global fallout in a different latitudinal zone, 766 respectively. ${ }^{239+240} \mathrm{Pu}$ inventories originate from previous publications $1,14,29,31,33,41,55,79$. 767 This figure was prepared with the free software Ocean Data View (ODV 5.1.2) (Schlitzer, 768 R., Ocean Data View, https://odv.awi.de, 2018) (a) and Sigma-Plot professional 10.0 769 software (b). 

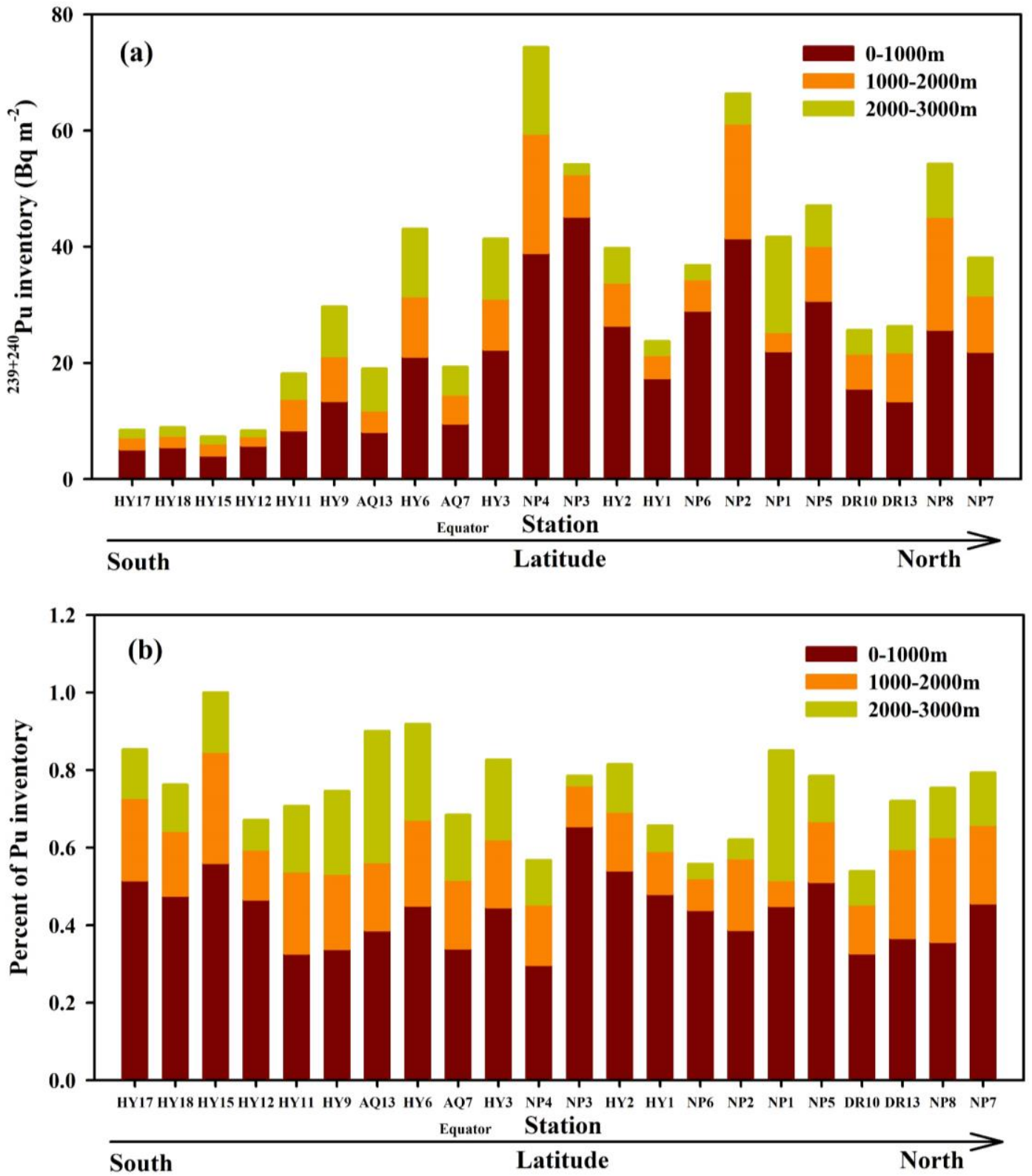

772 Figure 6. Vertical distribution of the ${ }^{239+240} \mathrm{Pu}$ inventory (a) and percent of the total (b) at 773 three different depth ranges and sampling stations. These figures were prepared with 774 Sigma-Plot professional 10.0 software. 


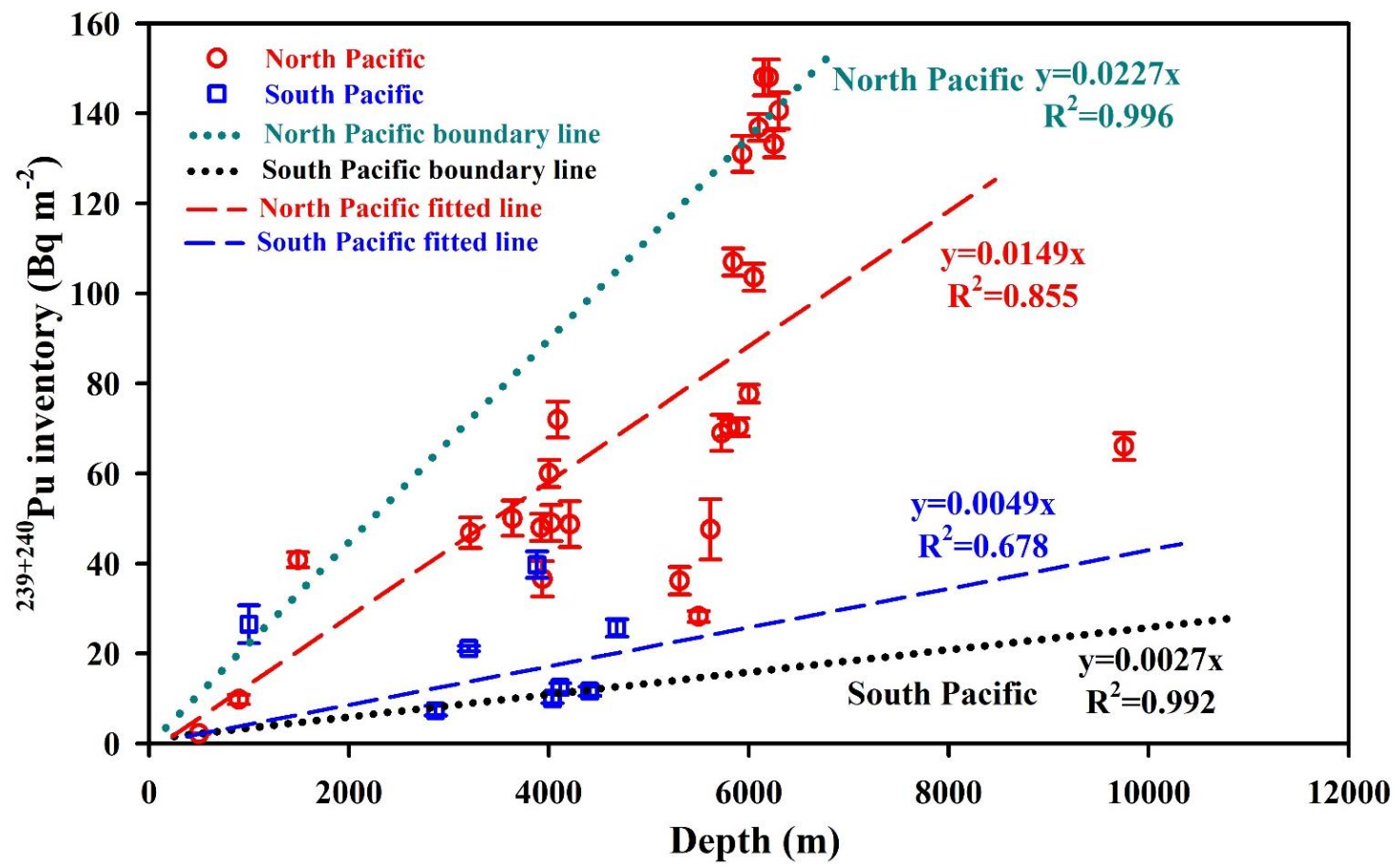

777 Figure 7. Linear fitted relationship between the ${ }^{239+240} \mathrm{Pu}$ inventory (y) and water depth (x) 778 in the Pacific Ocean. Values indicate the mean \pm standard deviation (SD); $\mathrm{R}^{2}=$ coefficient

779 of determination. This figure was prepared with Sigma-Plot professional 10.0 software. 


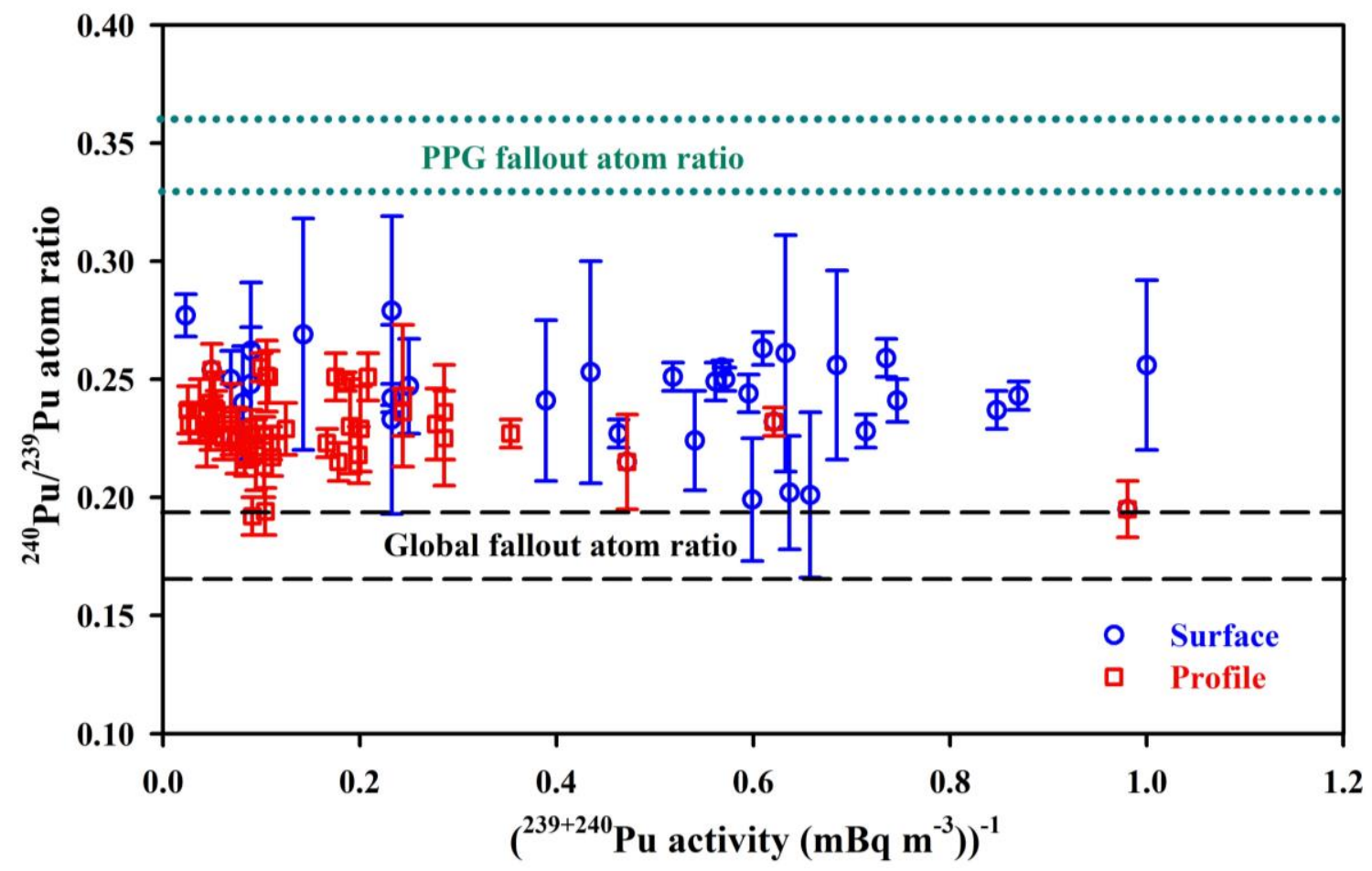

Figure 8. Relationship between the ${ }^{240} \mathrm{Pu} /{ }^{239} \mathrm{Pu}$ atom ratio and the reciprocal of ${ }^{239+240} \mathrm{Pu}$ activity for surface seawater and profile seawater in the Pacific Ocean. The blue circles represent the surface seawater data and the red squares indicate the profile seawater data. Horizontal black dashed lines represent the average ${ }^{240} \mathrm{Pu} /{ }^{239} \mathrm{Pu}$ atom ratio $(0.180 \pm 0.014)$

789 of global fallout ${ }^{63}$ and cyan dotted lines represent the range of the ${ }^{240} \mathrm{Pu} /{ }^{239} \mathrm{Pu}$ atom ratio $790(0.30-0.36)$ characteristic of the Pacific Proving Grounds $(P P G)^{10-11}$. This figure was 791 prepared with Sigma-Plot professional 10.0 software. 


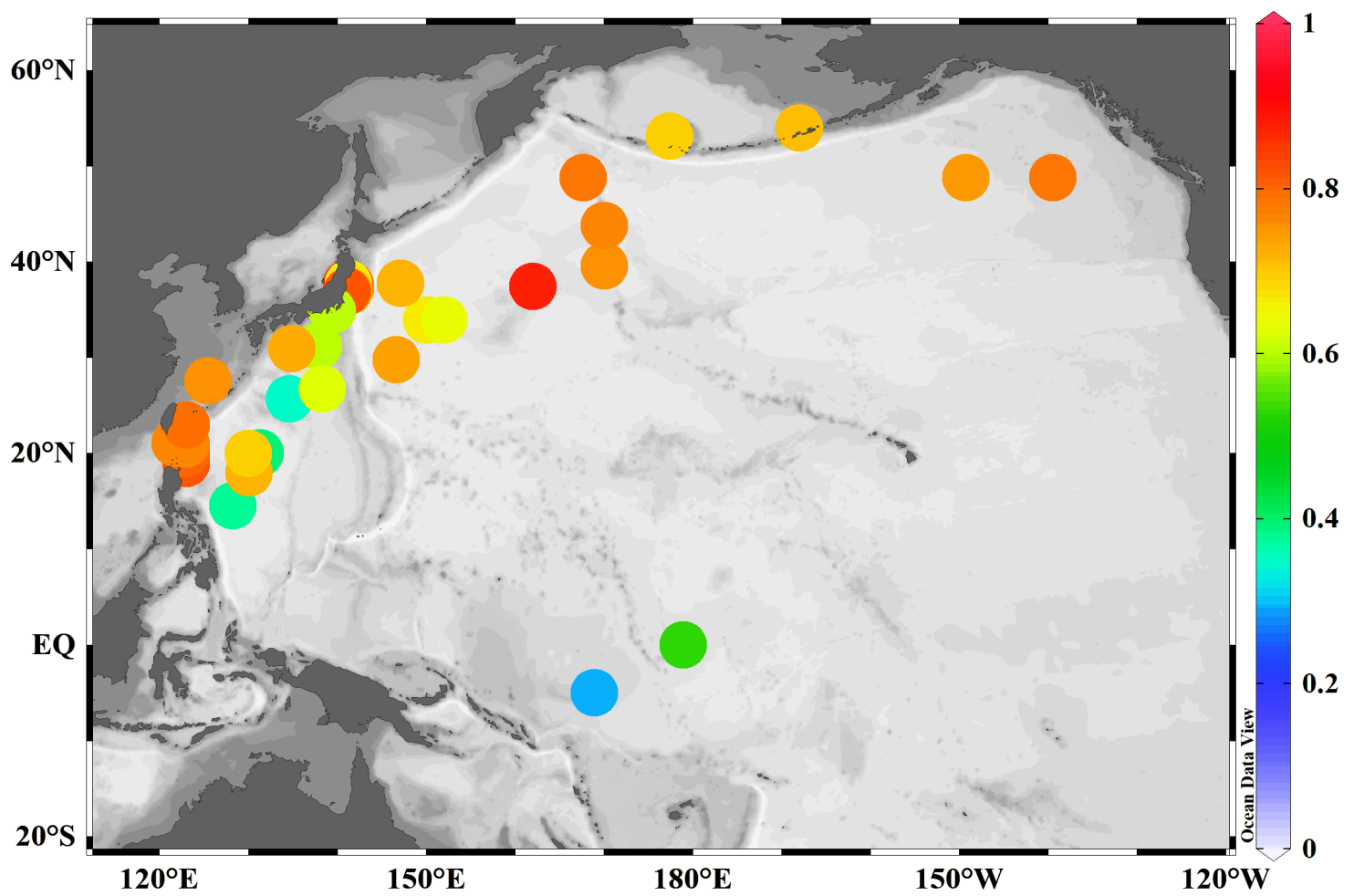

Figure 9. Spatial distribution of the contribution of $\mathrm{Pu}$ from the PPG to surface seawater in the Pacific Ocean. This map was drawn using the free software Ocean Data View (ODV 
Table 1. ${ }^{239+240} \mathrm{Pu}$ inventory in the Pacific Ocean and percent of the total at three different depth ranges

\begin{tabular}{|c|c|c|c|c|c|c|c|c|}
\hline \multirow{3}{*}{ station } & \multirow{3}{*}{$\begin{array}{c}\text { water } \\
\text { depth } \\
(\mathrm{m})\end{array}$} & \multicolumn{4}{|c|}{${ }^{239+240} \mathrm{Pu}$ inventory $\left(\mathrm{Bq} \mathrm{m}^{-2}\right)$} & \multicolumn{3}{|c|}{ Pu inventory percent } \\
\hline & & $0-1000 \mathrm{~m}$ & $0-2000 \mathrm{~m}$ & $0-3000 \mathrm{~m}$ & $0-\mathrm{bc}$ & $0-$ & $0-$ & $0-$ \\
\hline & & & & & & $1000 \mathrm{~m}$ & $2000 \mathrm{~m}$ & $3000 \mathrm{~m}$ \\
\hline HY17 & 4037 & $5.13 \pm 0.49$ & $7.24 \pm 0.70$ & $8.48 \pm 0.84$ & $9.94 \pm 1.02$ & $51.6 \%$ & $72.8 \%$ & $85.3 \%$ \\
\hline HY18 & 4411 & $5.54 \pm 0.38$ & $7.49 \pm 0.59$ & $8.88 \pm 0.74$ & $11.65 \pm 1.03$ & $47.6 \%$ & $64.3 \%$ & $76.2 \%$ \\
\hline HY15 & 2867 & $4.08 \pm 0.38$ & $6.17 \pm 0.83$ & $7.28 \pm 1.09$ & $7.28 \pm 1.09$ & $56.0 \%$ & $84.8 \%$ & $100.0 \%$ \\
\hline HY12 & 4114 & $5.79 \pm 0.46$ & $7.39 \pm 0.71$ & $8.34 \pm 0.86$ & $12.42 \pm 0.99$ & $46.6 \%$ & $59.5 \%$ & $67.2 \%$ \\
\hline HY11 & 4680 & $8.38 \pm 0.59$ & $13.83 \pm 0.98$ & $18.14 \pm 1.38$ & $25.66 \pm 1.97$ & $32.7 \%$ & $53.9 \%$ & $70.7 \%$ \\
\hline HY9 & 3882 & $13.46 \pm 1.26$ & $21.18 \pm 1.96$ & $29.65 \pm 2.46$ & $39.74 \pm 2.95$ & $33.9 \%$ & $53.3 \%$ & $74.6 \%$ \\
\hline AQ13 & 3200 & $8.17 \pm 0.25$ & $11.87 \pm 0.90$ & $21.17 \pm 1.80$ & $21.10 \pm 0.60$ & $38.7 \%$ & $56.3 \%$ & $90.1 \%$ \\
\hline HY6 & 3219 & $21.13 \pm 1.47$ & $31.52 \pm 2.46$ & $43.06 \pm 3.11$ & $46.87 \pm 3.39$ & 45. & $67.3 \%$ & $.9 \%$ \\
\hline AQ7 & 5500 & $9.60 \pm 0.41$ & $14.58 \pm 1.67$ & $19.29 \pm 2.12$ & $28.20 \pm 1.20$ & $34.0 \%$ & $51.7 \%$ & $68.4 \%$ \\
\hline HY3 & 3635 & $22.30 \pm 1.68$ & $31.09 \pm 2.47$ & $41.35 \pm 3.32$ & $50.03 \pm 3.92$ & $44.6 \%$ & $62.1 \%$ & $82.7 \%$ \\
\hline NP4 & 5933 & $38.95 \pm 2.71$ & $59.46 \pm 4.40$ & $74.34 \pm 6.80$ & $131.0 \pm 4.0$ & $29.7 \%$ & $45.4 \%$ & $56.8 \%$ \\
\hline NP3 & 5728 & $45.21 \pm 3.59$ & $52.51 \pm 4.77$ & $54.16 \pm 5.65$ & $69.0 \pm 4.0$ & $65.5 \%$ & $76.1 \%$ & $78.5 \%$ \\
\hline HY2 & 4208 & $26.40 \pm 2.07$ & $33.80 \pm 3.62$ & $39.72 \pm 4.22$ & $48.77 \pm 5.08$ & $54.1 \%$ & $69.3 \%$ & $81.4 \%$ \\
\hline HY1 & 5309 & $17.37 \pm 1.53$ & $21.37 \pm 2.08$ & $23.72 \pm 2.38$ & $36.13 \pm 3.07$ & $48.1 \%$ & $59.2 \%$ & $65.7 \%$ \\
\hline NP6 & 9754 & $29.02 \pm 2.64$ & $34.41 \pm 3.28$ & $36.80 \pm 3.73$ & $66.0 \pm 3.0$ & $44.0 \%$ & $52.1 \%$ & $55.8 \%$ \\
\hline NP2 & 5843 & $41.47 \pm 2.56$ & $61.22 \pm 4.17$ & $66.35 \pm 4.86$ & $107.0 \pm 3.0$ & $38.8 \%$ & $57.2 \%$ & $62.0 \%$ \\
\hline NP1 & 4085 & $22.04 \pm 2.29$ & $25.32 \pm 4.40$ & $41.65 \pm 6.25$ & 49. & $45.0 \%$ & $51.7 \%$ & $85.0 \%$ \\
\hline NP5 & 4004 & $30.73 \pm 3.55$ & $40.13 \pm 4.69$ & $47.08 \pm 5.77$ & $60.0 \pm 3.0$ & $51.2 \%$ & $66.9 \%$ & $78.5 \%$ \\
\hline DR10 & 5600 & $15.57 \pm 2.69$ & $21.60 \pm 3.43$ & $25.65 \pm 4.15$ & $47.56 \pm 6.73$ & $32.7 \%$ & $45.4 \%$ & $53.9 \%$ \\
\hline DR13 & 3930 & $13.42 \pm 1.21$ & $21.82 \pm 2.20$ & $26.32 \pm 2.86$ & $36.58 \pm 3.97$ & $36.7 \%$ & $59.7 \%$ & $72.0 \%$ \\
\hline NP8 & 4090 & $25.74 \pm 2.92$ & $45.14 \pm 5.67$ & $54.24 \pm 6.77$ & $72.0 \pm 4.0$ & $35.8 \%$ & $62.7 \%$ & $75.3 \%$ \\
\hline NP7 & 3920 & $21.89 \pm 3.66$ & $31.64 \pm 4.71$ & $38.07 \pm 5.61$ & $48.0 \pm 3.0$ & $45.6 \%$ & $65.9 \%$ & $79.3 \%$ \\
\hline
\end{tabular}

814

815

816

817 